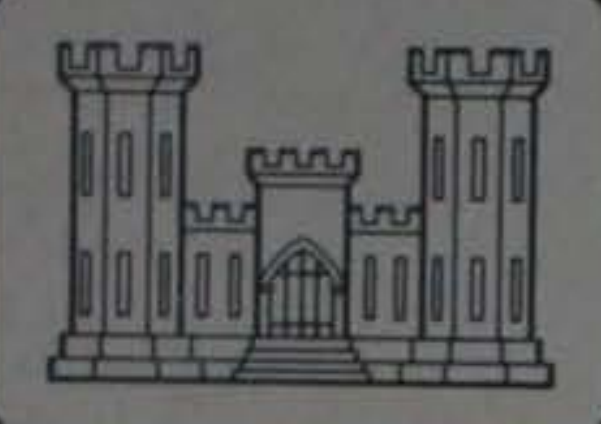

MISCELLANEOUS PAPER SL-81-15

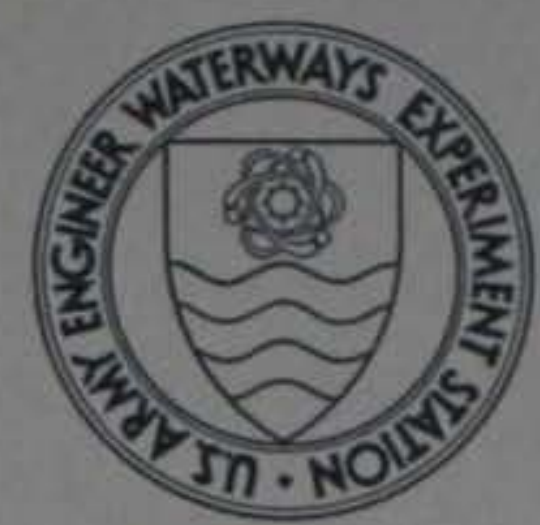

\title{
AN EXPEDIENT METHOD FOR EXCAVATION OF FOXHOLES
}

by

George A. Woodbury, Allen D. Rooke, Jr.

Structures Laboratory

U. S. Army Engineer Waterways Experiment Station

P. O. Box 631, Vicksburg, Miss. 39180

June 1981

Final Report

Approved For Public Release; Distribution Unlimited

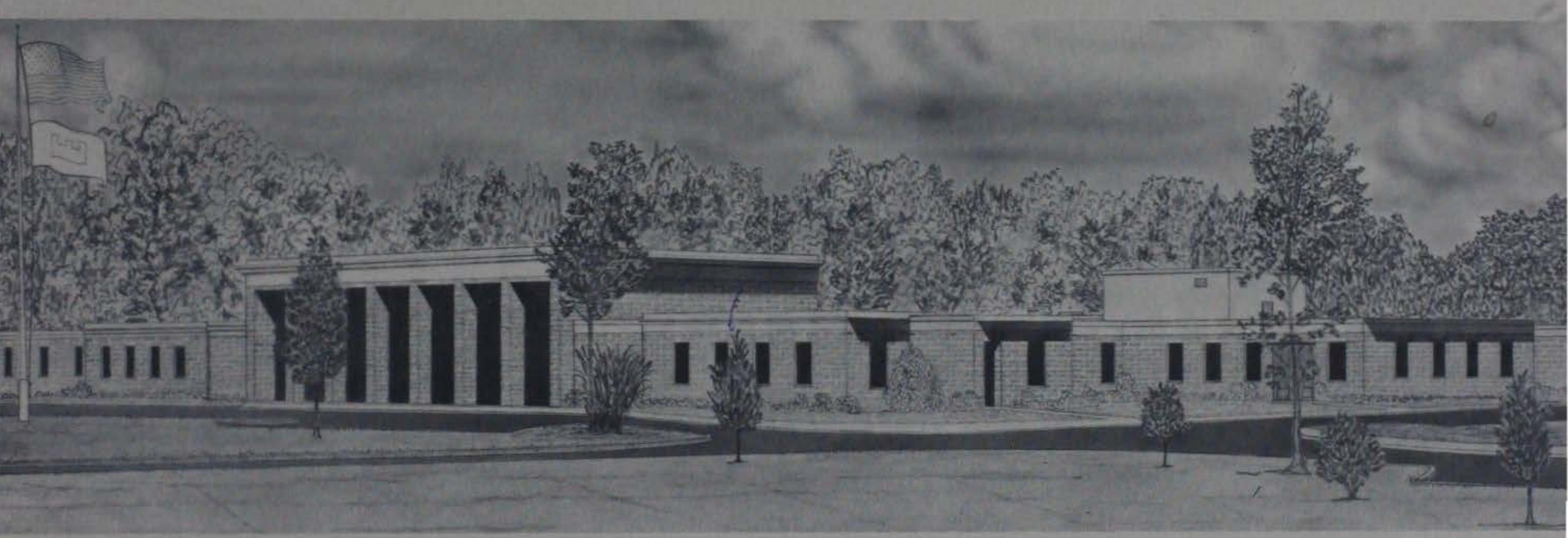

Prepared for Office, Chief of Engineers, U. S. Army

Washington, D. C. 20314

Under MEACE Project No. 4A762719AT40

LIBRARY BRANCH

TECHNICAL INFORMATION CENTER

US ARMY ENGINEER WATERWAYS EXPERIMENT STATION VICKSBURG, MISSISSIPPI 
Unclassified

SECURITY CLASSIFICATION OF THIS PAGE (When Data Entered)

\begin{tabular}{|c|c|}
\hline REPORT DOCUMENTATION PAGE & $\begin{array}{c}\text { READ INSTRUCTIONS } \\
\text { BEFORE COMPLETING FORM }\end{array}$ \\
\hline $\begin{array}{l}\text { 1. REPORT NUMBER } \\
\text { Miscellaneous Paper SL-81-15 }\end{array}$ & 3. RECIPIENT'S CATALOG NUMBER \\
\hline \multirow[t]{2}{*}{$\begin{array}{l}\text { 4. TITLE (and Subttie) } \\
\text { AN EXPEDIENT METHOD FOR EXCAVATION OF FOXHOLES }\end{array}$} & $\begin{array}{l}\text { 5. TYPE OF REPORT \& PERIOD COVERED } \\
\text { Final report }\end{array}$ \\
\hline & 6. PERFORMING ORG. REPORT NUMBER \\
\hline $\begin{array}{l}\text { 7. AUTHOR(a) } \\
\text { George A. Woodbury } \\
\text { Allen D. Rooke, Jr. }\end{array}$ & 8. CONTRACT OR GRANT NUMBER(B) \\
\hline $\begin{array}{l}\text { 9. PERFORMING ORGANIZATION NAME AND ADDRESS } \\
\text { U. S. Army Engineer Waterways Experiment Station } \\
\text { Structures Laboratory } \\
\text { P. O. Box } 631 \text {, Vicksburg, Miss. } 39180\end{array}$ & $\begin{array}{l}\text { 10. PROGRAMELEMENT, PROJECT, TASK } \\
\text { AREA \& WORK UNIT' NUMBERS } \\
\text { MEACE PrOjeCt } \\
\text { No. 4A762719AT40 }\end{array}$ \\
\hline $\begin{array}{l}\text { 11. CONTROLLING OFFICE NAME AND ADDRESS } \\
\text { office, Chief of Engineers, U. S. Army }\end{array}$ & $\begin{array}{l}\text { 12. REPORT DATE } \\
\text { June } 1981\end{array}$ \\
\hline Washington, D. C. 20314 & $\begin{array}{l}\text { 13. NUMBER OF PAGES } \\
45\end{array}$ \\
\hline 14. MONITORING AGENCY NAME \& ADDRESS(If different from Controlling Offico) & $\begin{array}{l}\text { 15. SECURITY CLASS. (of thio roport) } \\
\text { Unclassified }\end{array}$ \\
\hline & $\begin{array}{l}\text { 15a. DECLASSIFICATION/DOWNGRADING } \\
\text { SCHEDULE }\end{array}$ \\
\hline
\end{tabular}

16. DISTRIBUTION STATEMENT (of this Roport)

Approved for public release; distribution unlimited.

17. DISTRIBUTION STATEMENT (of the abstract ontered in Block 20, if different from Report)

\section{SUPPLEMENTARY NOTES}

Available from National Technical Information Service, 5285 Port Royal

Road, Springfield, Va. 22151.

19. KEY WORDS (Continue on reverse side if nocessery and Identify by block number)

Detonation Military operations

Expedient construction

Explosive excavation

Hand augers

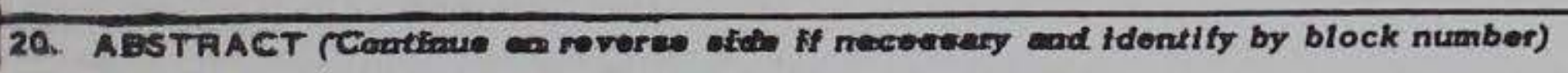

A technique involving standard demolitions and a modified entrenching tool is examined as an expedient means of rapidly constructing a foxhole. The basic design was developed in sandy, clayey silt, with limited tests in other materials. It consists of simultaneous detonation of two small charges, total energy yield being 1.5-1b TNT, one charge above the other. Except in rocky soils, which prevent augering and emplacement of the lower charge, the result

(Continued) 


\section{ABSTRACT (Continued).}

is a hole suitable for immediate cover and for improvement to meet standard foxhole criteria.

Background and requirements are discussed, along with advantages and disadvantages of this method of construction. It is recommended that this technique be adopted as an expedient, and that additional research and hardware development be conducted as necessary to standardize it. 
PREFACE

This study was conducted during FY 1977 under the sponsorship of the Office, Chief of Engineers, U. S. Army, as a part of the Military Engineering Applications of Commercial Explosives (MEACE) program under Project 4A762719AT40, "Mobility, Soils, and Weapons Effects Technology." It did not apply to any specific work unit and as such was not intended as a complete study leading to a problem solution. Rather, this test series was intended to determine if the concepts as presented herein had any merit which warranted further consideration.

Assisting in the field work were Messes. Sherman B. Price, John E. Shale, and Melvin Miller. This report was prepared by MAJ George A. Woodbury, Project Engineer, and by Mr. A. D. Rooke, Jr., Explosion Exfacts Division (EED), Structures Laboratory. Assisting in the preparatron of this report was Ms. Elizabeth Klein. Special appreciation is expressed to Mr. H. D. Carleton, who, as MEACE Project Officer, advised and encouraged this study. Mr. L. F. Ingram, Chief of the EED, provided general supervision. Mr. W. J. Flathau was the Chief of the Weapons Effects Laboratory (WEL) which conducted this investigation. A reorganization which occurred during the conduct of the study resulted in WEL being absorbed into a newly created Structures Laboratory, headed by Mr. Bryant Mather.

Commanders and Directors of WES during the conduct of this study and preparation of this report were COL John L. Cannon, CE and COL Nelson P. Conover, CE. Mr. F. R. Brown was the Technical Director.

1 


\section{PREFACE}

CONVERSION FACTORS, INCH-POUND TO METRIC (SI)

UNITS OF MEASUREMENT

PART I

\section{Background}

Preliminary Considerations

Objectives

PART II: DESCRIPTION OF STUDY

Charge Design . . . . . . . . . . . . . 7

Auger Design Concept ............... 7

Test Conditions . . . . . . . . . . . . . . 11

PART III: TEST RESULTS . . . . . . . . . . . . . . . 22

Auger Performance . . . . . . . . . . . . . 22

Explosive Design Performance ............ 22

PART IV: DISCUSSION, CONCLUSIONS, AND RECOMMENDATIONS . . . . 23

Discussion ................... . . 23

Conclusion ................. . . . 23

Recommendations .............. . . 24

REFERENCES ............................. 26

TABLES 1 and 2

APPENDIX A: STANDARDS FOR FOXHOLE CONSTRUCTION . . . . . . . A1

APPENDIX B: 1977 CONFERENCE ON EXPLOSIVE FOXHOLE EXCAVATION • . BI 
Inch-pound units of measurement used in this report can be converted to metric (SI) units as follows:

\begin{tabular}{|c|c|c|}
\hline Multiply & By & To Obtain \\
\hline feet & 0.3048 & metres \\
\hline feet per pound (mass)* & 0.6720 & metres per kilogram \\
\hline grains & 0.00006480 & kilograms \\
\hline inches & 2.54 & centimetres \\
\hline pounds (mass) & 0.4536 & kilograms \\
\hline pounds per cubic foot & 16.02 & kilograms per cubic metre \\
\hline
\end{tabular}

* Assuming equivalence between weight and mass, e.g. $1 b_{\text {force }}=1 b_{\text {mass }}$. 


\section{PART I: INTRODUCTION}

\section{$\underline{\text { Background }}$}

1. U. S. forces employed in mobile combat operations need a rapid method to prepare dug-in positions for individual and crew-served weapon protection. Presently, the individual soldier must rely on hand tools to accomplish this.

2. During the early 1970 's, an explosive "foxhole"* digging aid was procured and field tested. This device relied on a small shaped charge to prepare an emplacement hole for a small cratering charge. The cratering charge loosened the soil, reducing the effort required to excavate it with hand tools. This device is no longer in production because of unacceptable reliability and other problems, such as acoustic and visual signatures. In October 1977, a meeting was held at Fort Belvoir, Virginia, to review previous work and to redefine requirements. As an invitee, the U. S. Army Engineer Waterways Experiment Station (WES) was provided an opportunity to present an alternative approach to the problem (Appendix B, meeting announcement and minutes).

3. Preliminary investigation into the meeting's stated purpose clearly indicated the potential for a new research effort, which could significantly delay introduction of an acceptable item into the field. It was also apparent that this effort would be directed at a two-shot kit having a shaped charge and a cratering charge. During the short time available between notification and the meeting, it was decided to undertake an effort to see if the task might be accomplished using existing equipment and demolitions, with the hope that the outcome could serve as a "quick fix," or might simply be included in appropriate

* Widely accepted name for an individual dug-in field fortification. Appendix A shows idealized dimensions of individual and crew-served weapons positions. 
literature (school texts and field manuals) as an expedient solution to rapid construction of foxholes.

\section{$\underline{\text { Preliminary Considerations }}$}

4. Shaped-charge designs have not achieved clean boreholes with an acceptable degree of reliability.* An alternative to the shaped charge is hand-augering of a pilot borehole for charge emplacement. The charge size can be chosen to suit soil conditions and the size of emplacement desired. The disadvantages of hand-augering are that it takes more time and effort and may be impossible in extremely rocky or frozen soils; however, the shaped charge also performs poorly in rocky or frozen soils.

5. Weight and bulk are additional considerations. Infantry and airborne soldiers, who are most in need of a rapid entrenching device, are penalized by additional tools or equipment that must be carried.

6. Finally, the capability to prepare a position with maximum safety and minimum notification to the enemy is an important consideration. The loud noise from above-ground explosions limits the usefulness of a shaped charge for this purpose. The shaped charge also creates a missile hazard during detonation.

\section{Objectives}

7. Test objectives were:

a. To explosively construct an individual dug-in position that would provide immediate protection to the individual soldier, and which could be improved with time to approach the dimensions of the field-manual foxhole. Initial desired hole dimensions were $4 \mathrm{ft} * *$ in surface diameter and 3.5-ft depth.

b. To restrict total weight of explosive and additional equipment to $4 \mathrm{lb}$.

* A problem currently under study at WES under a separate work unit. ** A table of factors for converting inch-pound units of measurement to metric (SI) units is presented on page 3 . 
c. To permit adaptability such that charge size could be varied to suit soil conditions.

d. To maximize safety and reliability while minimizing signature. 


\section{Charge Design}

8. If total kit weight were to be restricted to $4 \mathrm{lb}$, and if the auger (discussed below) were to weigh about $1 \mathrm{lb}$, it was necessary that the total explosive weigh no more than $3 \mathrm{lb}$. It has been observed that a charge buried at near-optimum depth will excavate a crater whose diameter is approximately twice its depth. Further, cratering capability curves (Figures 1 and 2 ) show that, for the soil conditions at the test site, a charge on the order of 1-1b TNT or less could be expected to create a crater with the desired 4-ft diameter when detonated at a depth of about 1.5 to $2.0 \mathrm{ft}$. To obtain the additional depth needed for the foxhole, it would be necessary to add one or more charges below the first charge. Obviously, the simplest workable design was the most desirable; hence, the two-charge concept came into being. The second charge would necessarily be near containment depth, usually taken as $\sim 3.5 \mathrm{ft} / 1 \mathrm{~b}^{1 / 3}$. Figure 3 illustrates this concept. While some advantage might be realized by placing a delay between the two charges, this was eliminated from consideration as an unnecessary complication, and also because delay caps are not common to military demolitions. Thus, the simple concept of a simultaneous two-charge geometry formed the basis for the testing of various combinations of charge weights and depths to establish an optimum design.

\section{Auger Design Concept}

9. In order to avoid the necessity for a new piece of equipment, it seemed desirable to adapt an auger to the soldier's entrenching tool. This approach minimizes weight, bulk, and development time. The length of the auger is determined by two factors: (1) charge depth of burial (DOB) requirements, and (2) the design of the entrenching tool. The folded length of the entrenching tool is approximately 9 in., therefore, the best length for the auger sections would also be 9 in. The handle of the tool without the spade attached has a usable length for borehole 


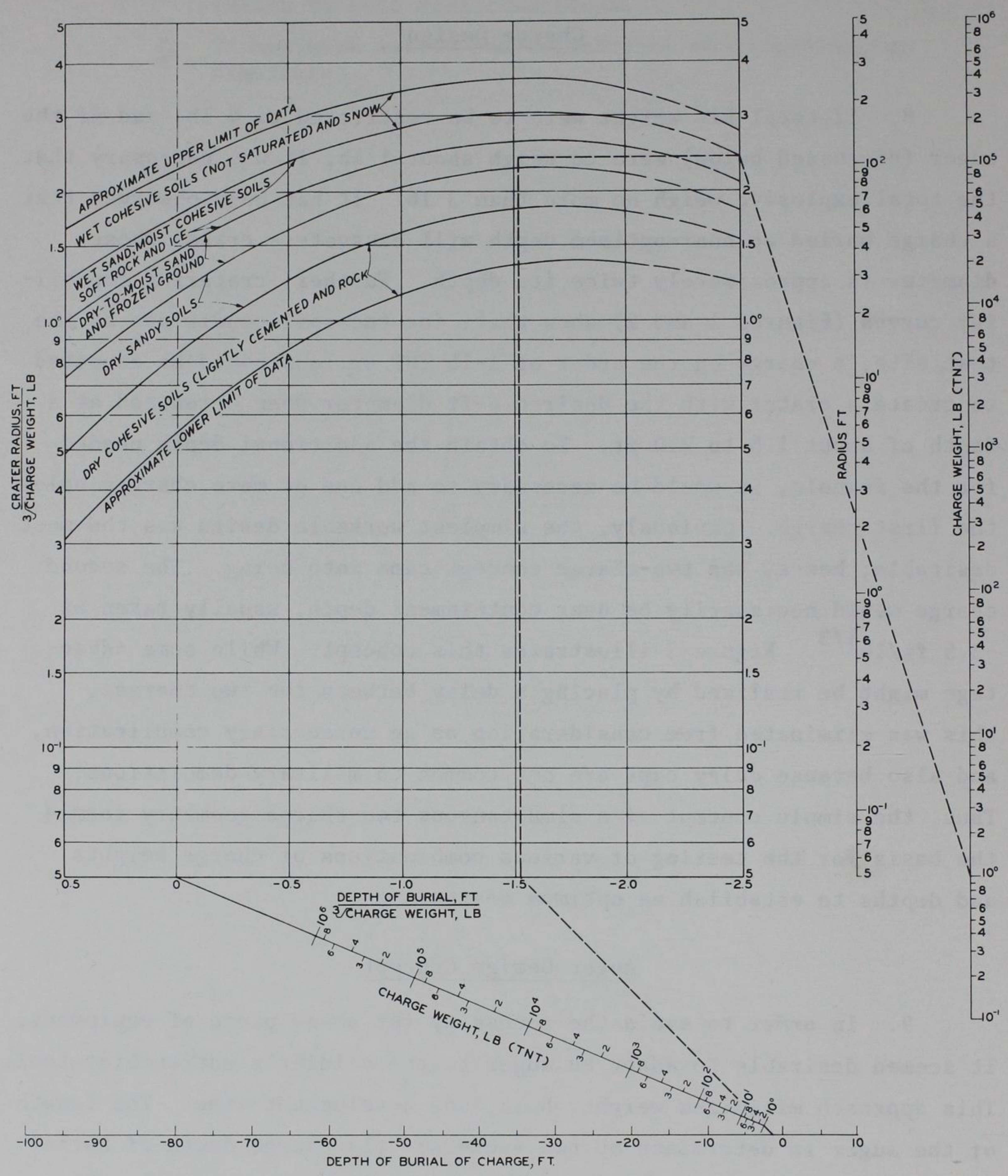

Figure 1. Nomograph for crater radius adapted from Strange (1961). Dashed lines illustrate use for a small charge typical to this study; entry may be from either bottom or right-hand scale, depending upon information sought 


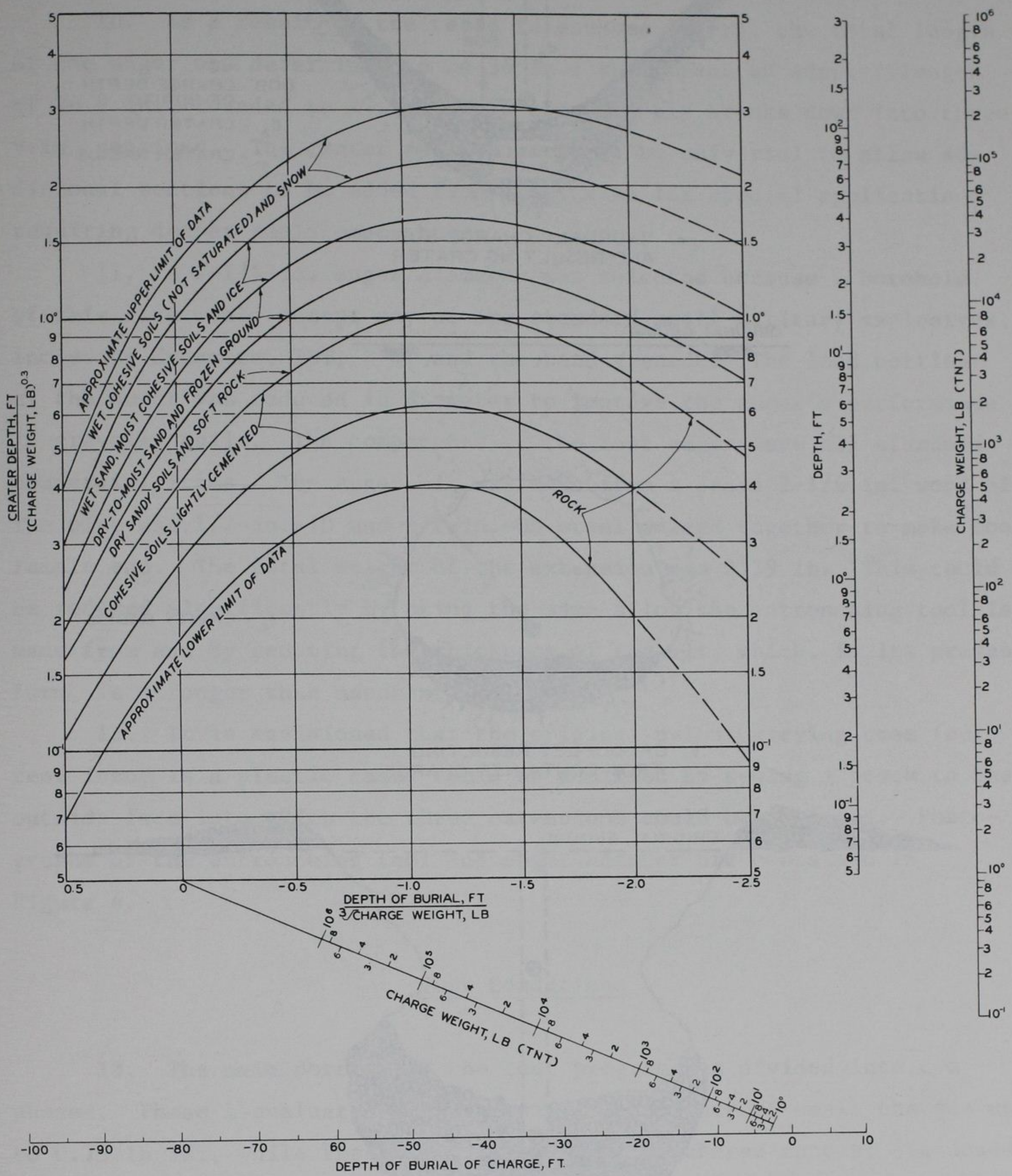

Figure 2. Nomograph for crater depth adapted from Strange (1961). See Figure 1 for example of use 


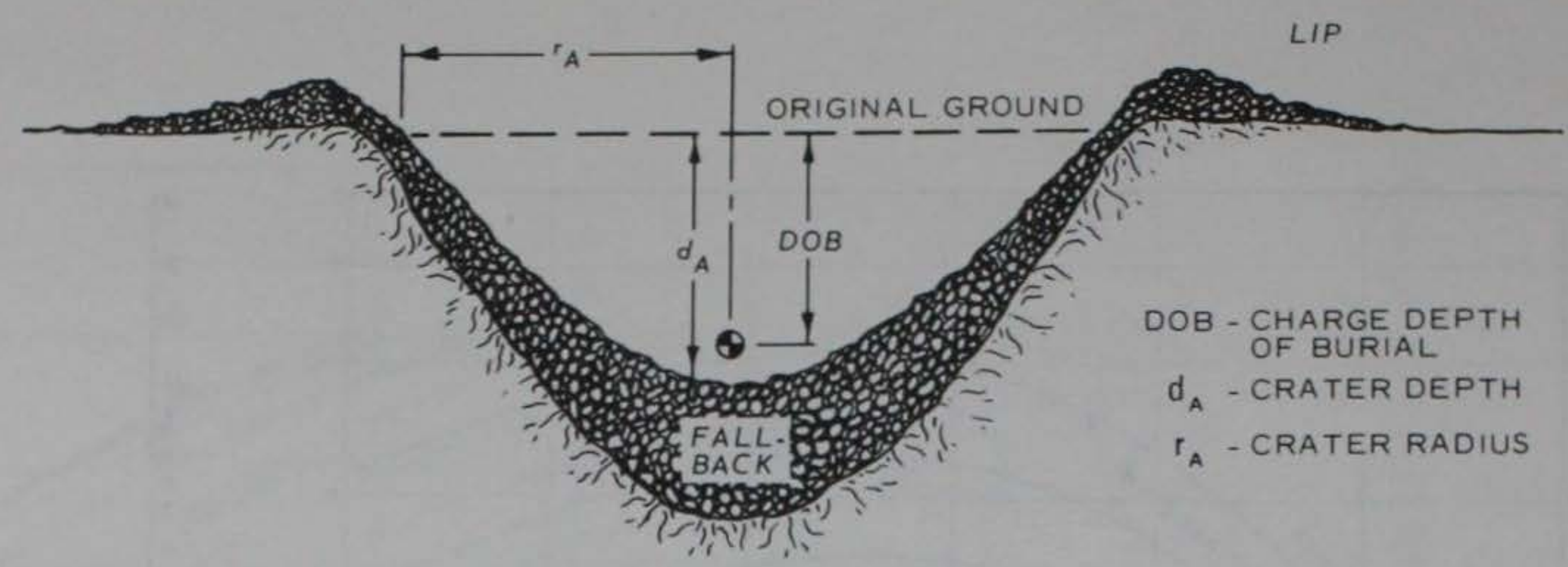

a. "NORMAL" CHARGE BURIAL AND RESULTING CRATER

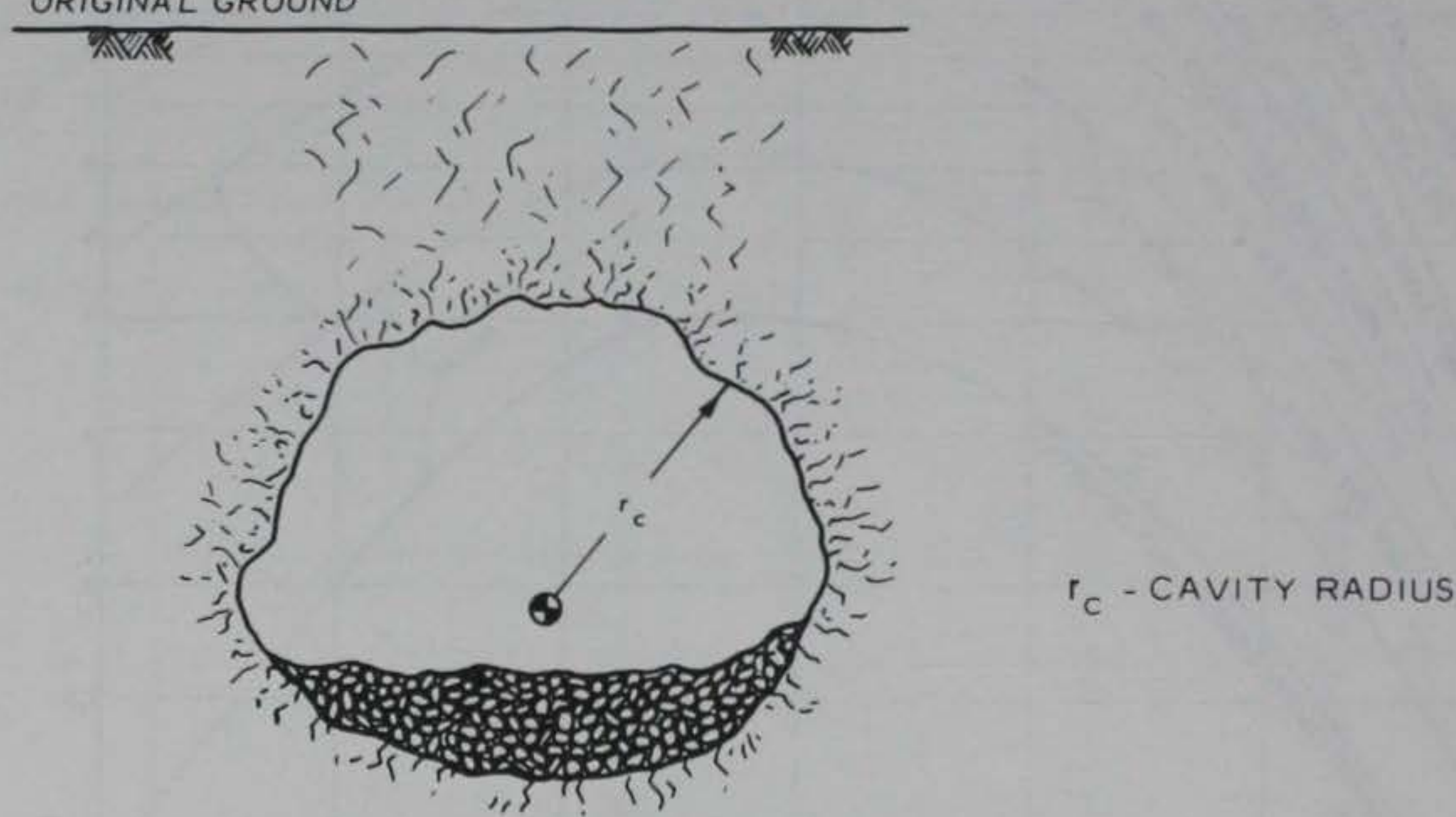

b. CAMOUFLET RESULTING

FROM CONTAINED CHARGE

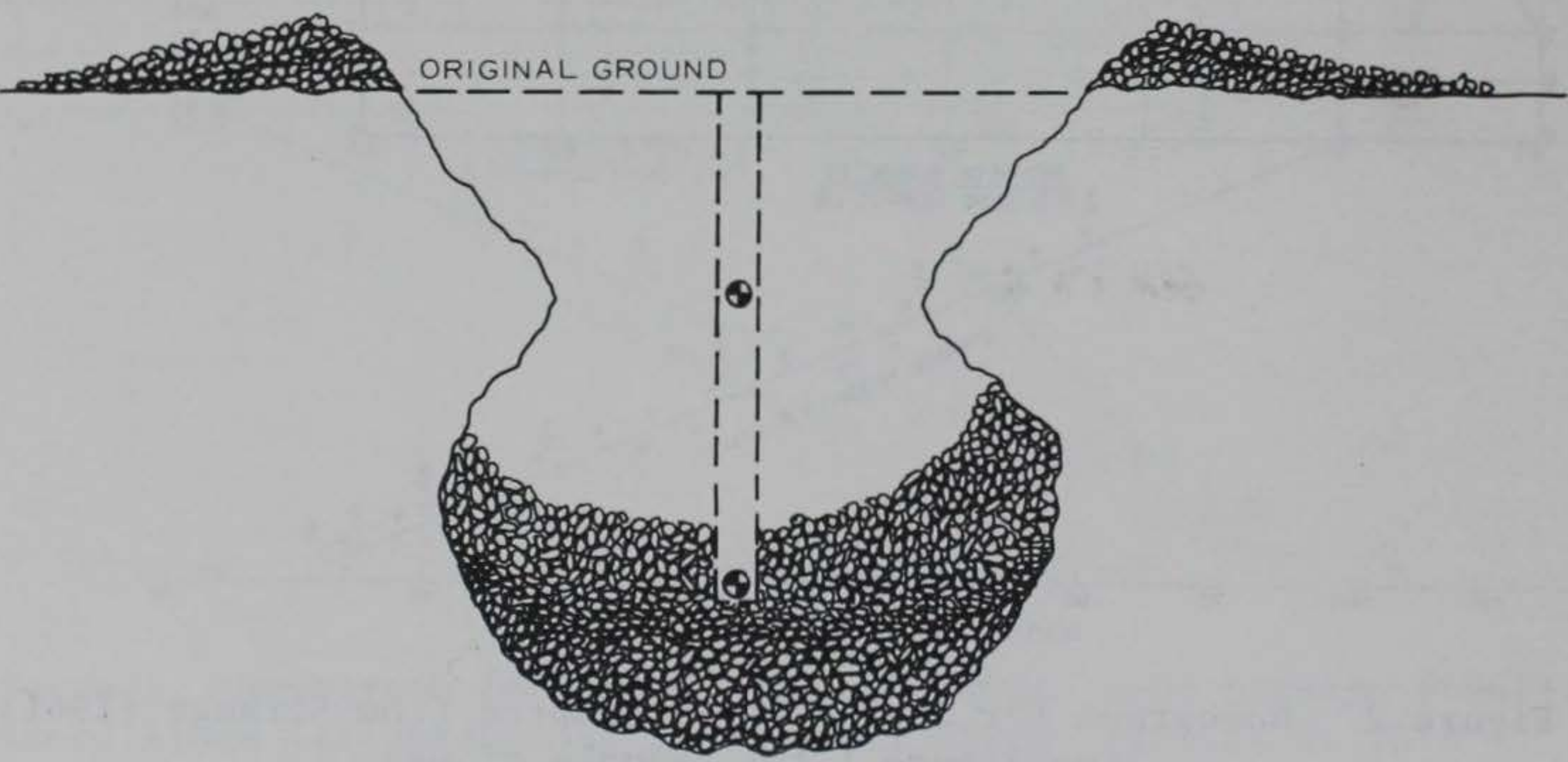

c. TWO-CHARGE

CRATER

Figure 3. Concept of two-charge foxhole 
augering of 9 in. Thus, the required auger adaption length became charge borehole requirement, less 9 in.

10. As a result of the tests (discussed later), the total length of the auger was determined to be $36 \mathrm{in.;}$ this meant an adapter length of $26.9 \mathrm{in.}$, rounded to $27 \mathrm{in}$. This conveniently breaks down into three 9-in. sections. The center section needs to be universal to allow additional sections to be added from other kits for special applications requiring deeper emplacement holes.

11. A 2-1/4-in. auger diameter was selected because a borehole of this size would accept any of the standard small military explosives, including dynamite, TNT, $\mathrm{C}-4$, and the hand grenade. The lead portion of the auger was reduced in diameter to improve the auger's performance in gravelly soils. The components of the test auger were all standard commercial items. The auger bit was made from a Sears 2-1/4-in. wood bit. The pipe was 1/2-in.-ID and 1/2-in.-OD steel welded together to make the female end. The total weight of the extension was $2.39 \mathrm{lb}$. This could be reduced significantly by using the same alloy the entrenching tool is made from and by reducing the thickness of the bit, which, in its present form, is stronger than necessary.

12. It is envisioned that the original nylon carrying case (current issue is a plastic case) could be modified by sewing a pouch to the outside face into which the three extensions could be inserted. Photographs of the entrenching tool and auger adapter are contained in Figure 4 .

\section{Test Conditions}

13. The main portion of the test program was divided into two phases. Phase 1 evaluated the cratering performance of small charges up to $0.75 \mathrm{lb}$ TNT, while Phase 2 evaluated the two-charge concept discussed above. These tests were conducted at the WES Big Black Test Site (BBTS) (Figure 5). In general, the soil at this site is characterized as a sandy, clayey silt (CL-ML) in the Unified Soil Classification System. Borings reveal a thick layer of silt, interspersed with sand and some 


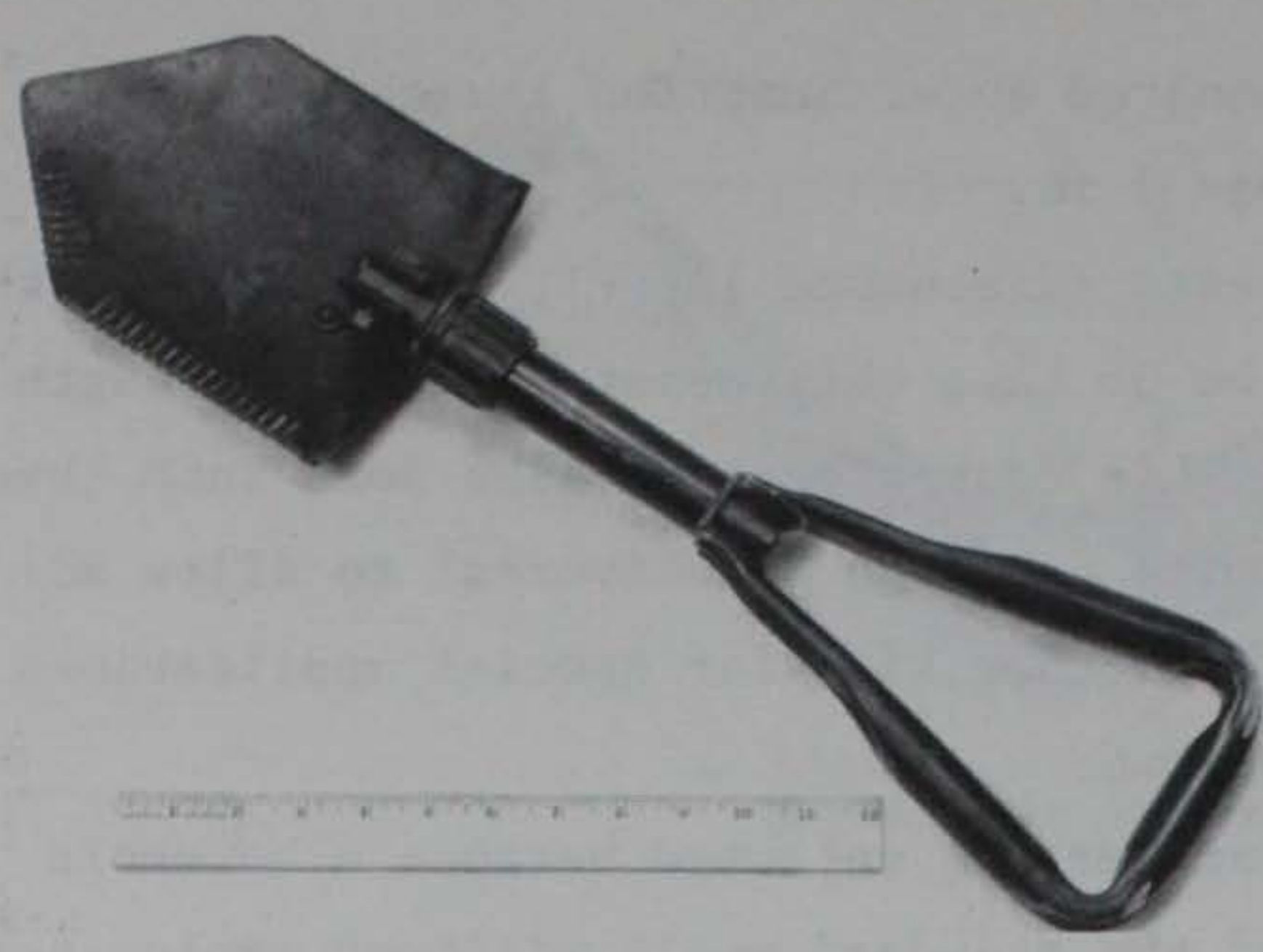

a. Tool ready for use

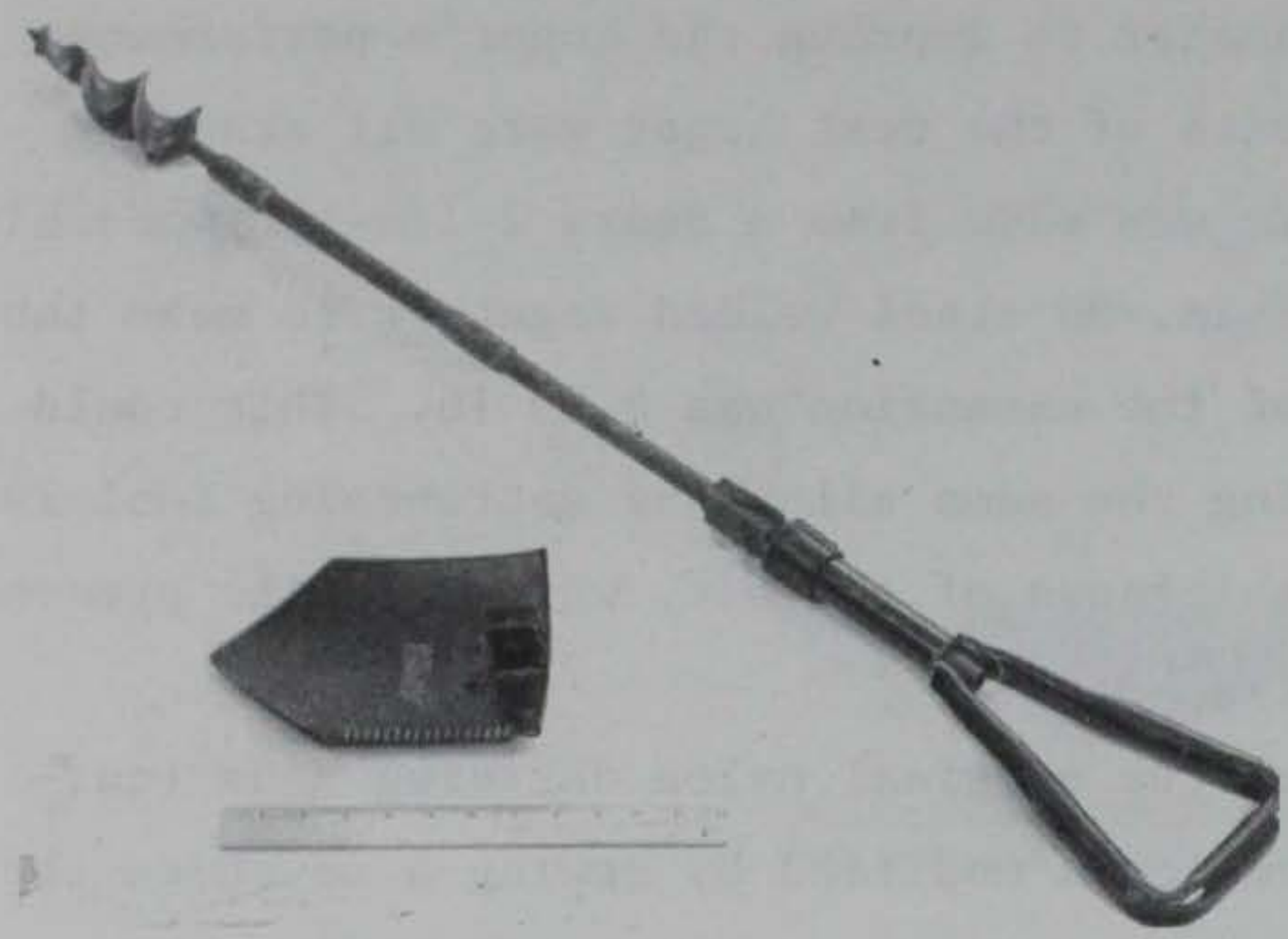

b. Tool with auger substituted for shovel

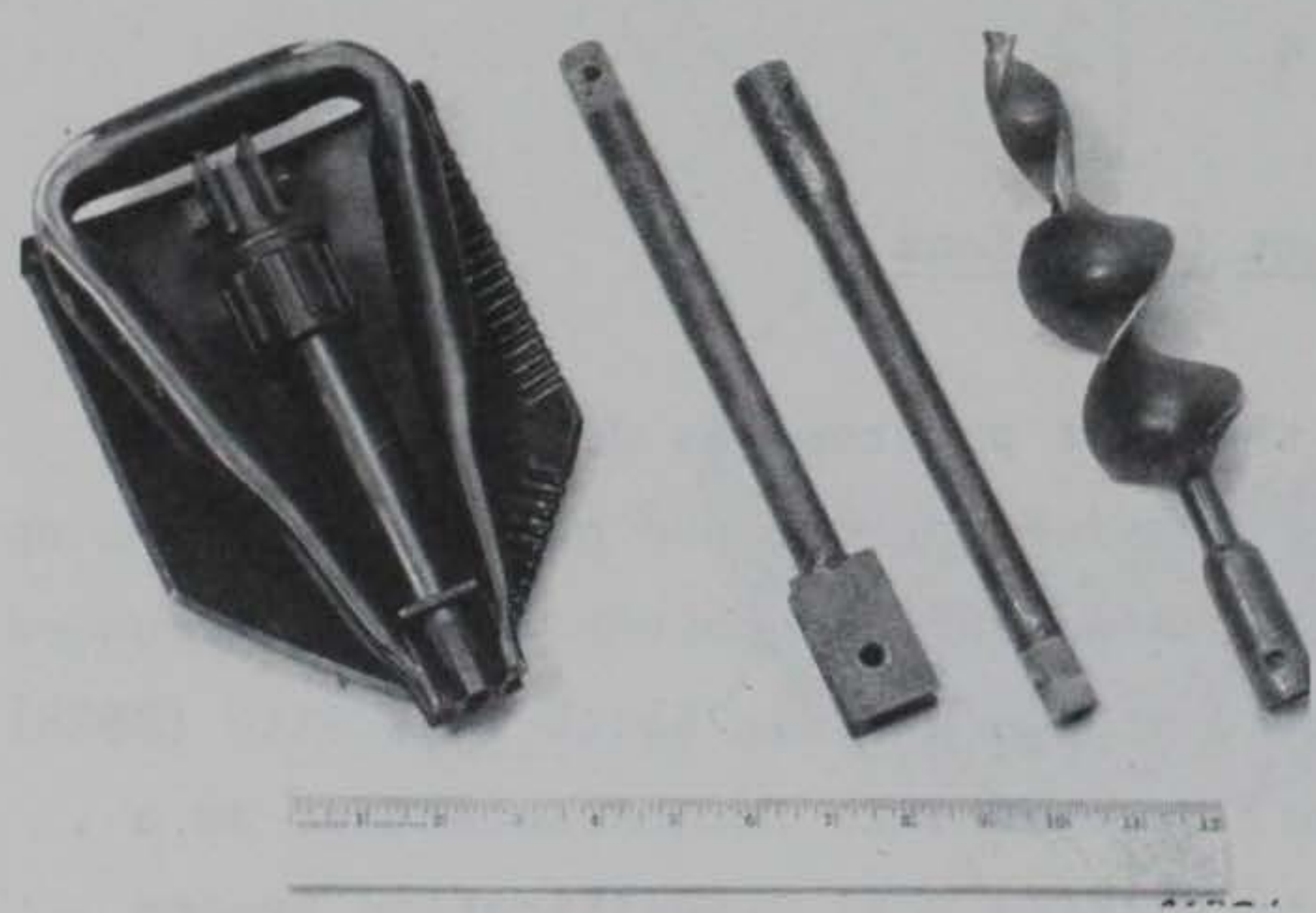

c. Folded entrenching tool and disassembled auger

Figure 4. Entrenching tool and auger adaptation 


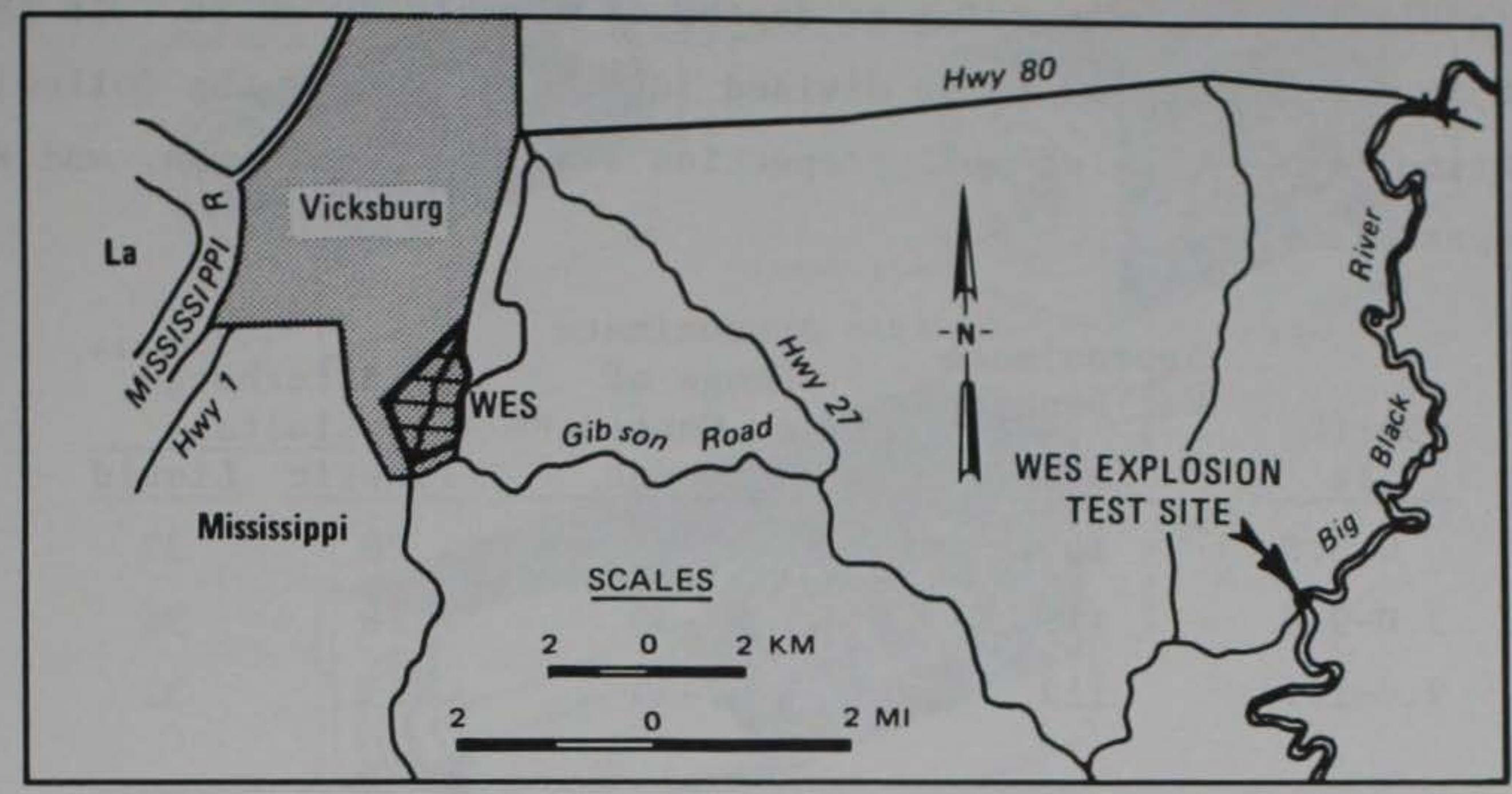

a. Vicinity map of WES Big Black Test Site

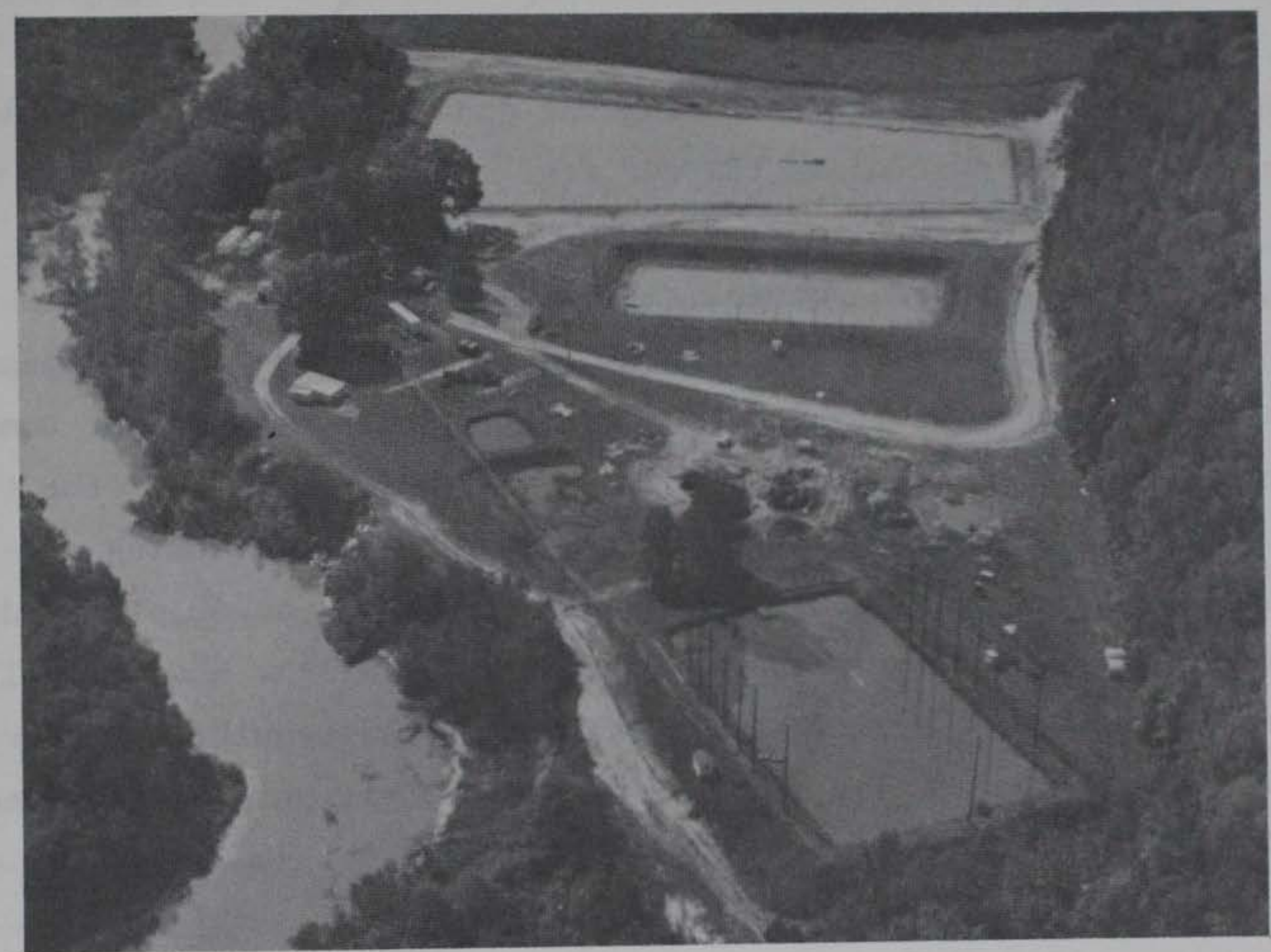

b. Aerial view of WES Test Site on Big Black River Figure 5. WES Big Black Test Site 
clay down to a depth of about $40 \mathrm{ft}$, where it is underlain by gravel and marl. The water table varies both seasonally and with proximity to the Big Black River, occurring at depths of roughly 20-30 ft. If the top $20 \mathrm{ft}$ are considered to be divided into three zones, the following tabulation can be made of soil properties (Carleton, Sullivan, and Rooke in preparation).

\begin{tabular}{|c|c|c|c|c|}
\hline \multirow{2}{*}{$\begin{array}{c}\text { Depth } \\
\mathrm{ft}\end{array}$} & \multirow{2}{*}{$\begin{array}{l}\text { Approximate } \\
\text { Wet Density* } \\
1 \mathrm{~b} / \mathrm{ft}^{3} \\
\end{array}$} & \multirow{2}{*}{$\begin{array}{l}\text { Approximate } \\
\text { Range of } \\
\text { Water Content**} \\
\text { Percent } \\
\end{array}$} & \multicolumn{2}{|c|}{$\begin{array}{l}\text { Atterberg } \\
\text { Limits }\end{array}$} \\
\hline & & & Plastic & Liquid \\
\hline $0-3.0$ & 100 & $10-28$ & 28 & 32 \\
\hline $3.0-9.8$ & 112 & $25-30$ & 23 & 36 \\
\hline $9.8-19.7$ & 119 & $27-30$ & 25 & 32 \\
\hline
\end{tabular}

\footnotetext{
* Varies with water content.

$* *$ During times of normal test operations; excluding extreme conditions.
}

Soil moisture was not measured during the conduct of these tests, but was estimated at 18-22 percent at the surface.

Phase 1

14. A11 tests were accomplished with standard $1 / 4-1 b$ blocks of TNT (Figure 6) primed with 50-grain (50 grains per foot) detonating cord, and were intended to verify previous results (Strange 1961) for the particular locations and soil moisture conditions existing at the time of these tests. Charge emplacement holes were hand-augered using a 2-1/4in.-diam auger having similar characteristics to the auger pictured in Figure 4. Charge DOB was measured to the center of the charge. A11 charges were stemmed (backfilled and tamped). The resulting craters were measured for depth and diameter using the original, undisturbed ground surface as a reference. Figure 7 illustrates hand augering procedure and shows a typical foxhole crater.

Phase 2

15. For the two-charge array of Phase 2, a near-camouflet depth was sought for the lower charge, thereby creating a chamber whose true bottom (below the fallback) would be approximately $4.0 \mathrm{ft}$ deep. This 


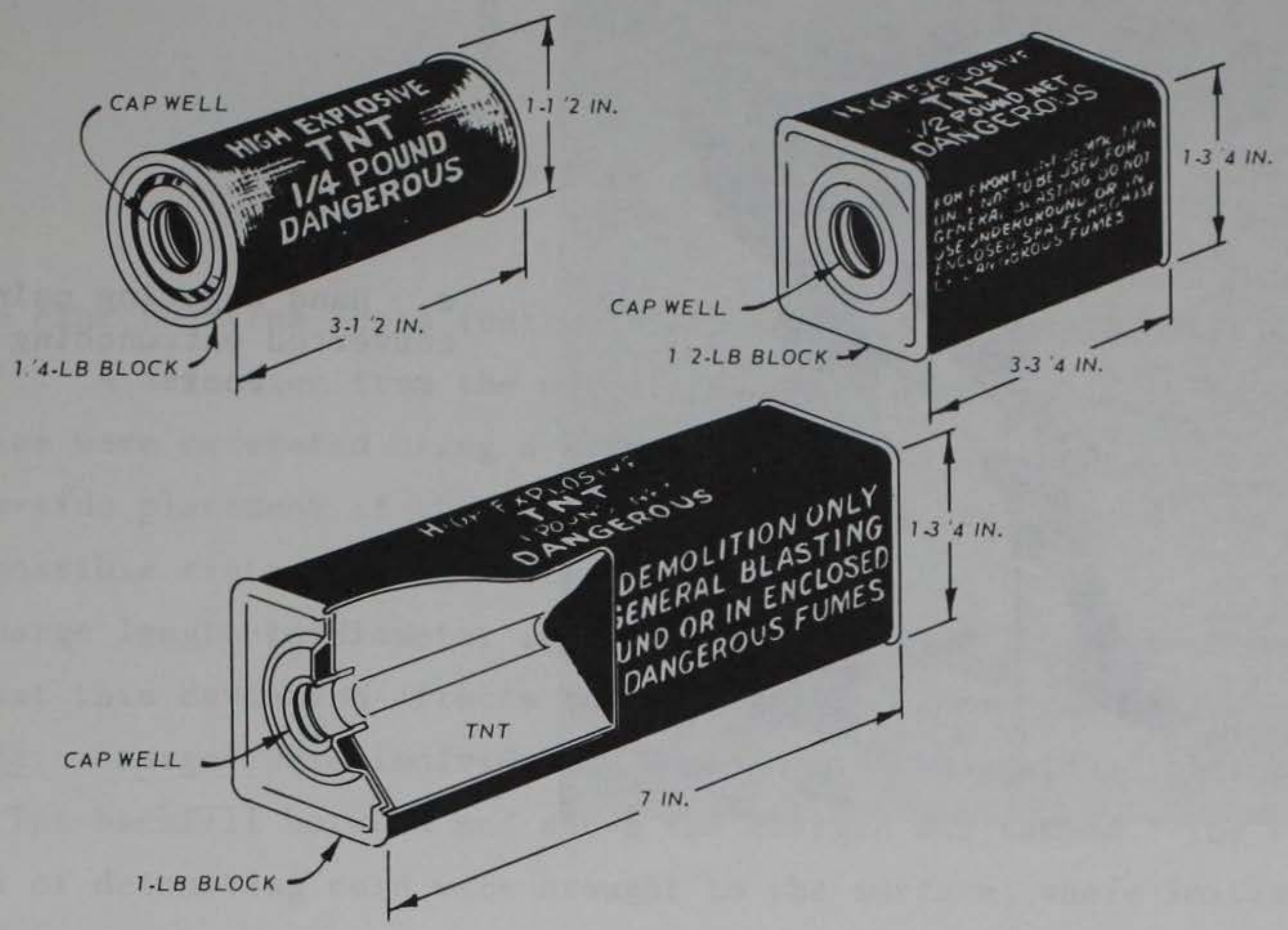

Figure 6. TNT block explosives used in tests (U. S. Army Field Manual 5-25 1971)

depth was considered optimum for completion of the foxhole, to include construction of the grenade sump (Figure A1). For the BBTS, camouflet diameter $D$ can be estimated by

$$
D=(2.3 \pm 0.4) W^{1 / 3}
$$

where

$$
\begin{aligned}
& \mathrm{D}=\text { feet } \\
& \mathrm{W}=\text { charge weight in 1b TNT (Strange 1961) }
\end{aligned}
$$

16. A nominal 3-ft borehole depth was selected as the best depth for testing variations of small charges. Note, for example, that a 1-1b charge (Figure 6 ) would have a charge center $36.0-3.5=32.5$ in. below ground surface. Adding from this point the expected radius of a camouflet, 


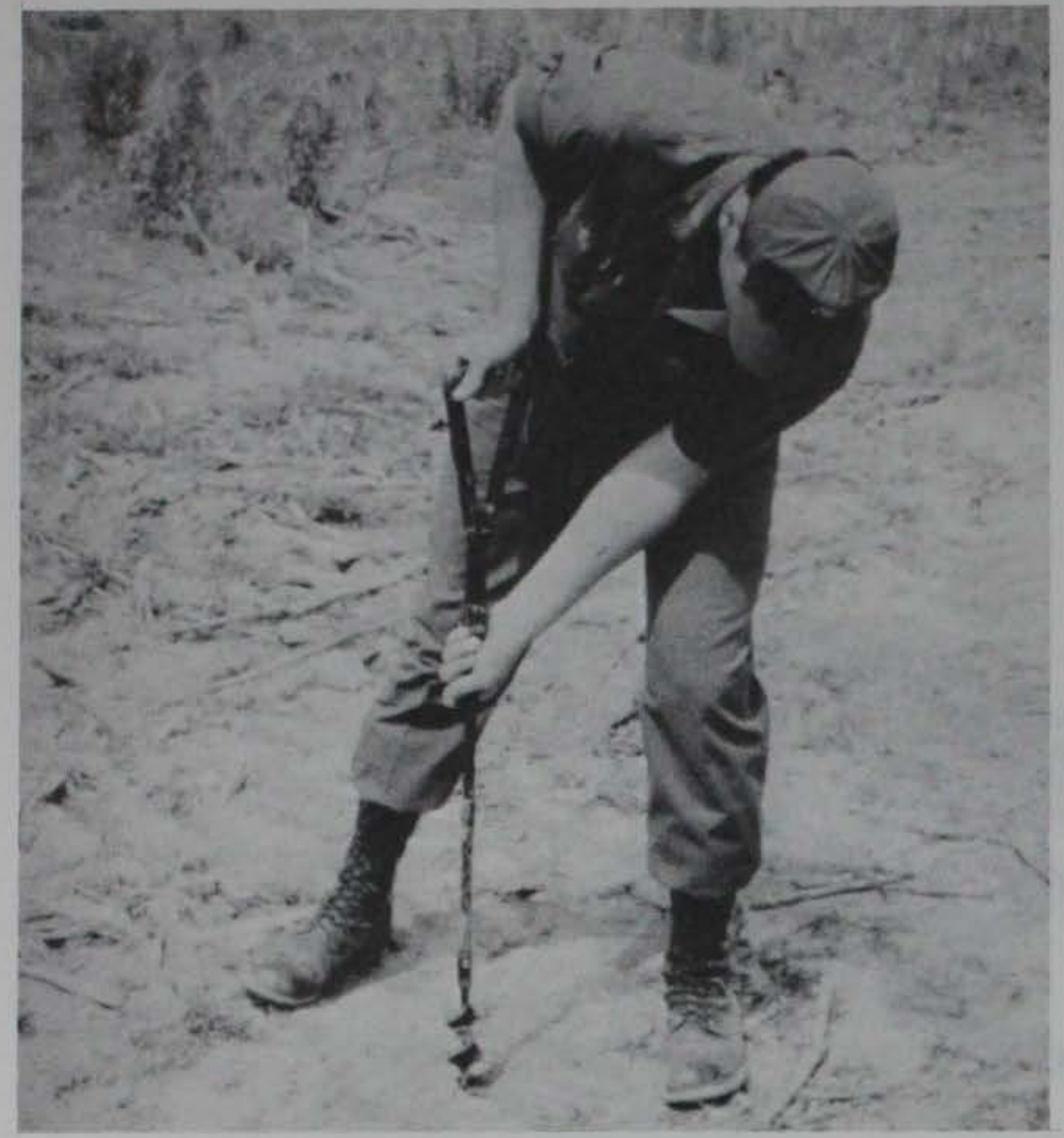

a. Hand augering using converted entrenching tool

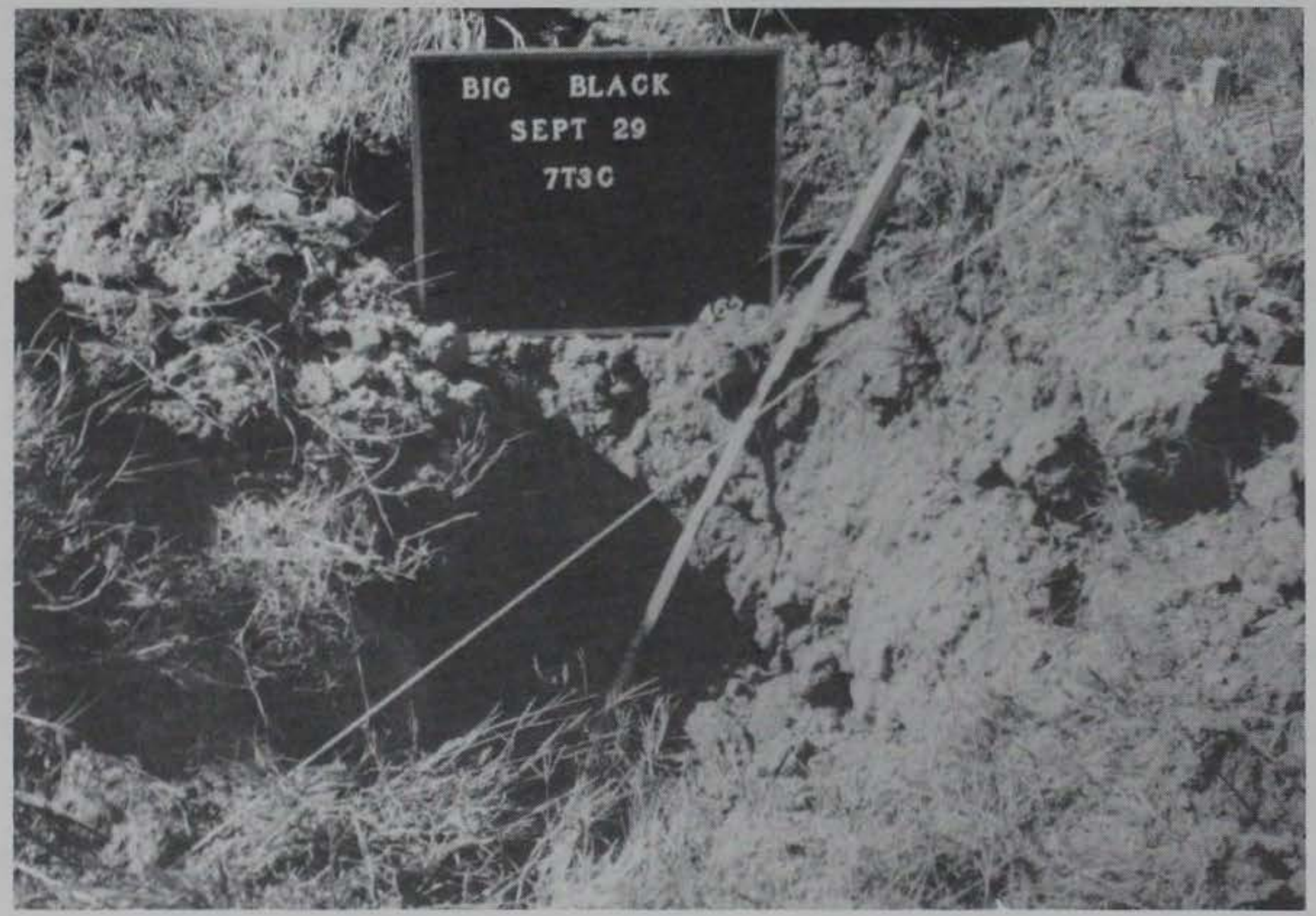

b. Typical

foxhole

crater re-

sulting

from Phase 1

single-

charge tests

Figure 7. Hand-augering procedure and resulting typical foxhole crater 


$$
\begin{aligned}
\frac{D}{2} & =\frac{2.3(1.0)^{1 / 3}}{2} \\
& =1.15 \mathrm{ft}
\end{aligned}
$$

and the expected true depth (bottom of loose soil) becomes $3.86 \mathrm{ft}$.

17. A deviation from the normal procedure occurred in Phase 2: boreholes were excavated using a 4-in. auger. This was done to permit side-by-side placement of the TNT charges where necessary, and thus to avoid possible cratering degradation due to elongated charges. In this way, charge length-to-diameter ratios were kept below 1.5. It is not felt that this deviation affects the results of recommendations.

18. Charges were individually boosted with 50-grain detonating cord. The backfill between and above the charges was tamped. The two lengths of detonating cord were brought to the surface, where initiation was effected by a No. 8 blasting cap.

\section{Additional tests}

19. There were limited opportunities to test the auger in soils other than the BBTS. Such tests were accomplished in conjunction with other projects. These locations, along with descriptions of nearsurface soils, are given in the following paragraphs.

20. Harry S. Truman Reservoir, Warsaw, Missouri. The test site was in a bend of the Osage River (Figure 8 ). The soil was a mixture of sand, silt, and clay, with a high percentage of fine material and with a predominant classification of CL. It was underlain by limestone/ dolomite bedrock at a depth of about $33 \mathrm{ft}$. The water table was estimated at depths between 11-14 ft. Moisture content ranged from 18 to 26 percent in the upper $10 \mathrm{ft}$, increasing below this depth. The liquid limit ranged from 20 to 39 percent, and the plastic limit from 13 to 17 percent, making the samples fall within the plastic range (Carleton, Sullivan, and Rooke in preparation).

21. Fort Leonard Wood, Missouri. The site (Figure 9) is characterized as native dolomite and sandstone overlain by $5-20 \mathrm{ft}$ of 


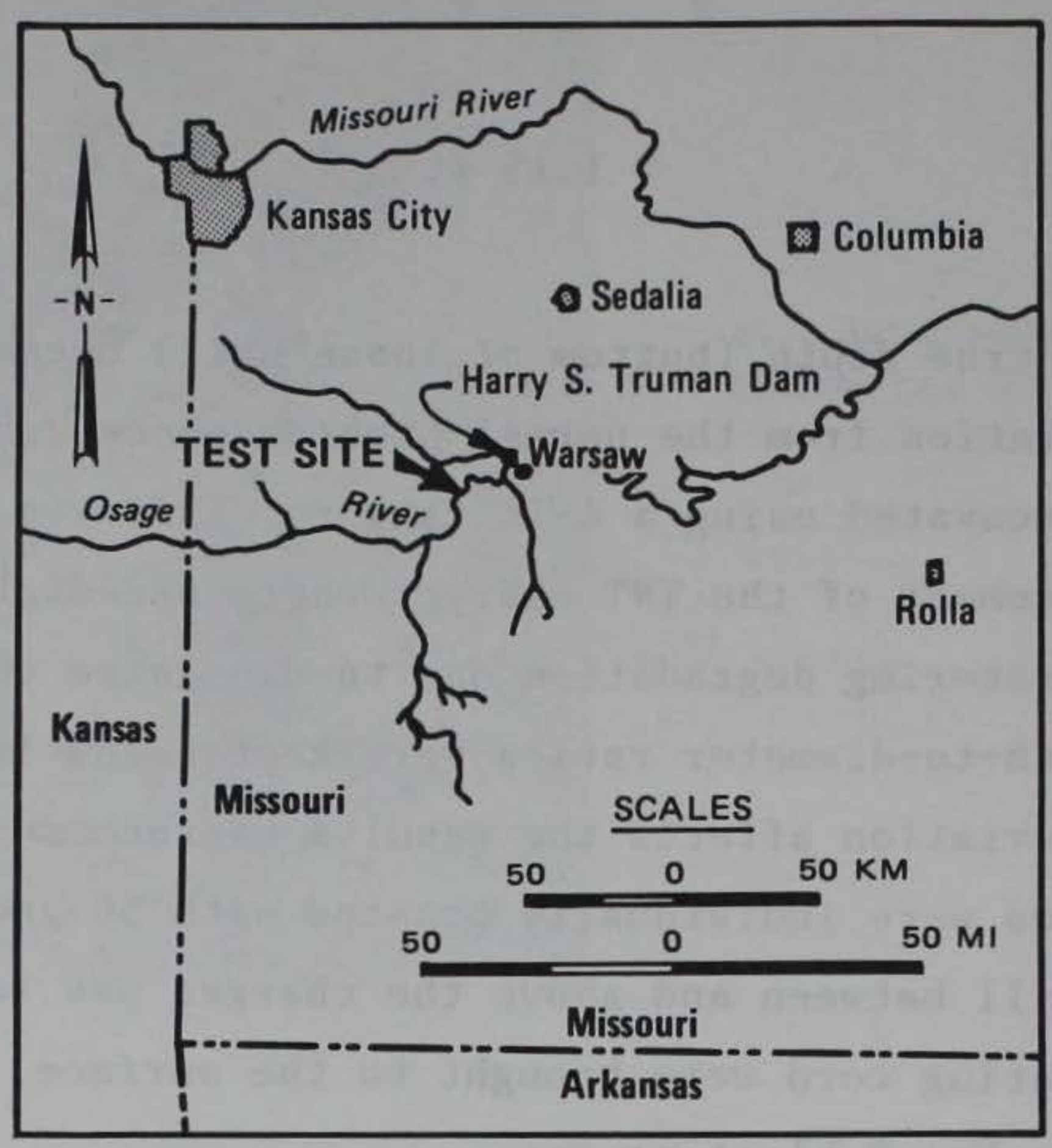

a. Vicinity map (Rand McNa11y

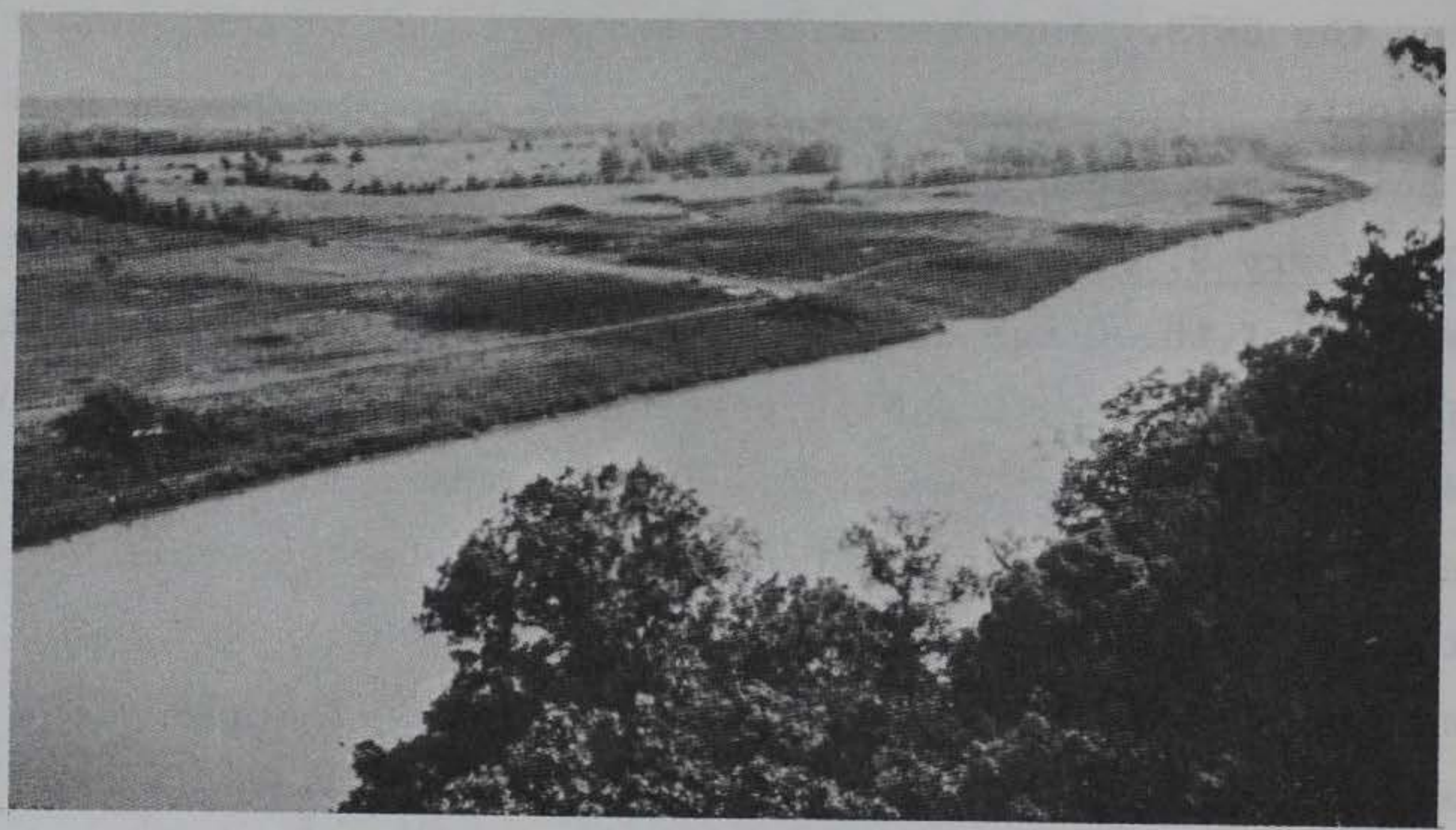

b. Site photograph

Figure 8. Harry S. Truman Reservoir test site 
a. Vicinity map (Rand ilcivally 1978)

b. C1oseup view of soil

$$
\text { at test site }
$$
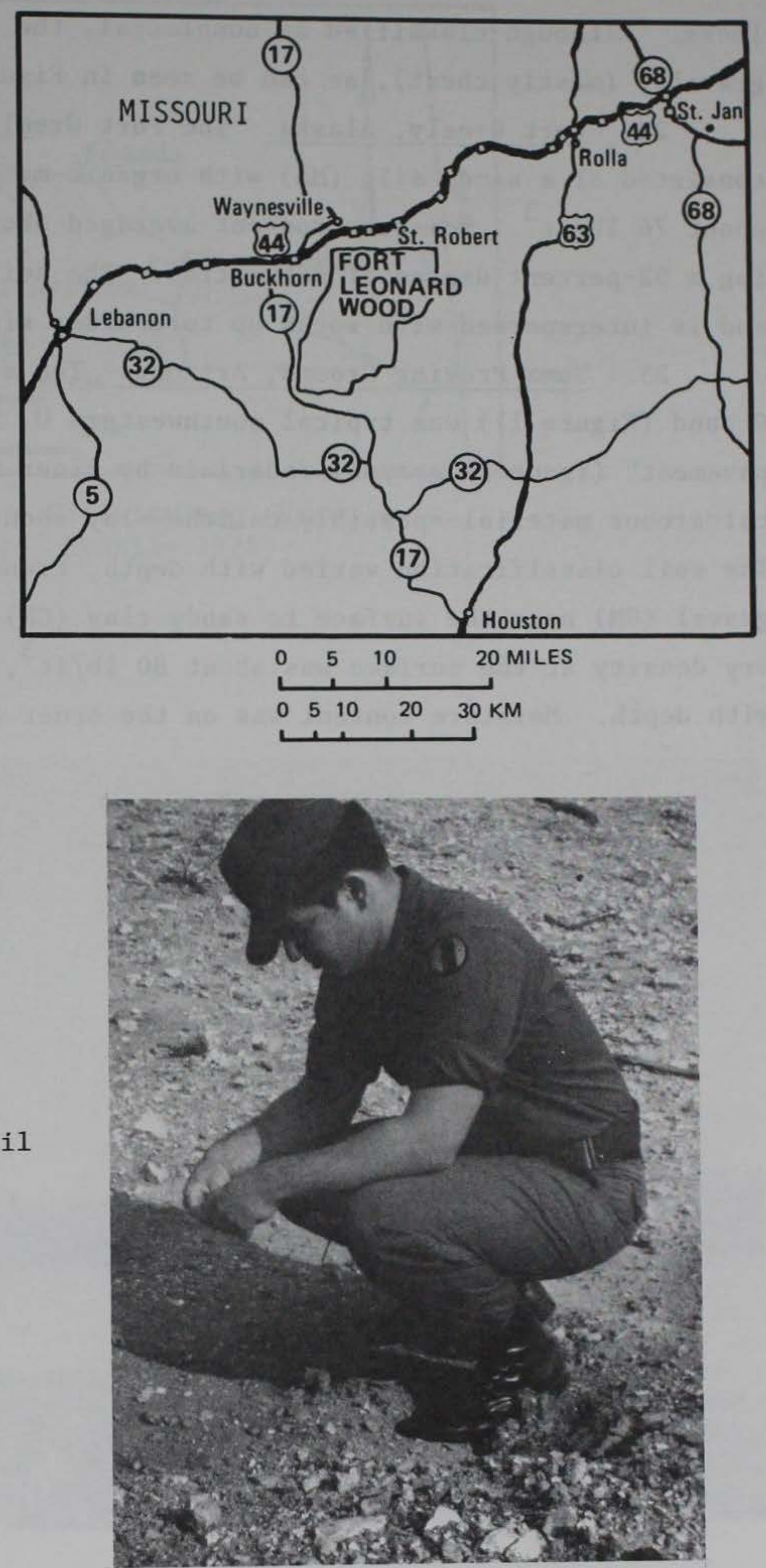

Figure 9. Vicinity map of Fort Leonard Wood and photograph of surface soil texture 
loess. Although classified as nonglacial, the surface geology is gravelly (mostly chert), as can be seen in Figure 9 .

22. Fort Greely, Alaska. The Fort Greely site (Figure 10) consisted of a sandy silt (ML) with organic matter, average dry density about $76 \mathrm{lb} / \mathrm{ft}^{3}$. Moisture content averaged about 40 percent, representing a 92-percent degree of saturation. The soil is glacial in origin and is interspersed with rocks up to boulder size.

23. Yuma Proving Ground, Arizona. The site at Yuma Proving Ground (Figure 11) was typical southwestern U. S. desert, with "desert pavement" (igeneous gravel) underlain by finer material. A stratum of calcareous material--possibly caliche--lay about $2 \mathrm{ft}$ below the surface. The soil classification varied with depth, trending from sandy, silty gravel (GM) near the surface to sandy clay (CH) at a depth of $20 \mathrm{ft}$. Dry density at the surface was about $80 \mathrm{lb} / \mathrm{ft}^{3}$, becoming somewhat denser with depth. Moisture content was on the order of 3 percent. 


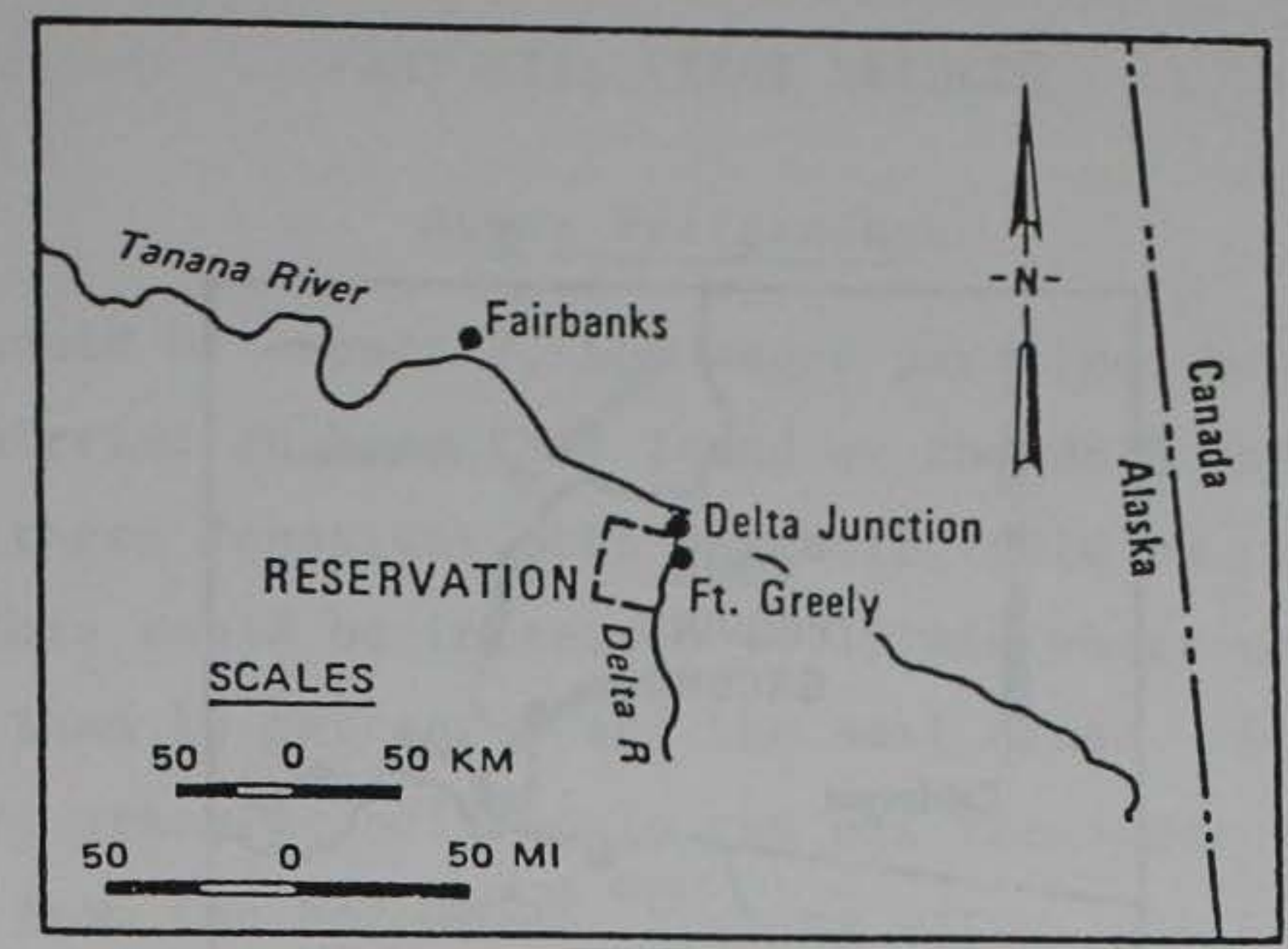

a. Vicinity map (Rand

McNally 1978)

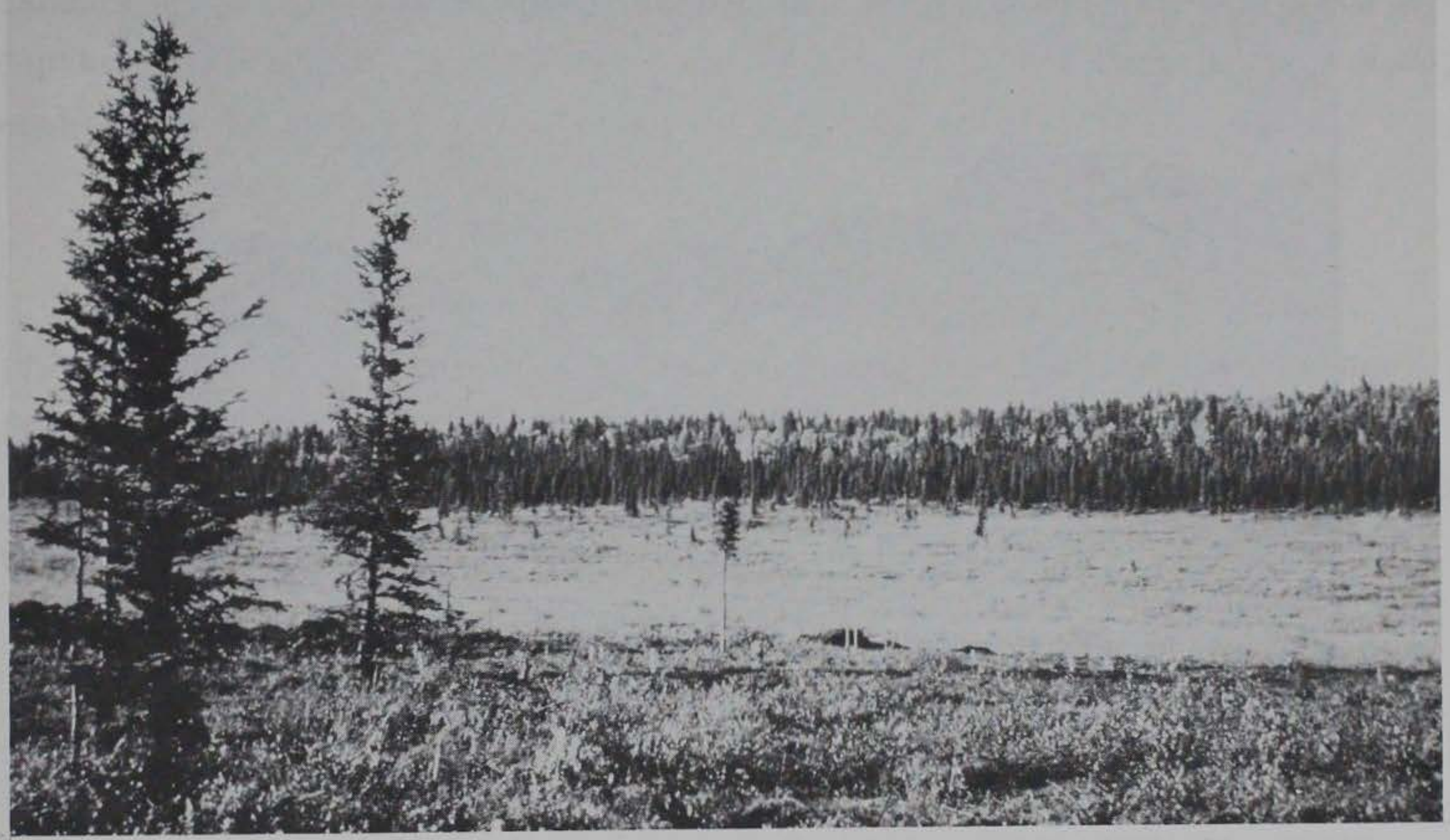

b. Site photograph

Figure 10. Fort Greely test site 


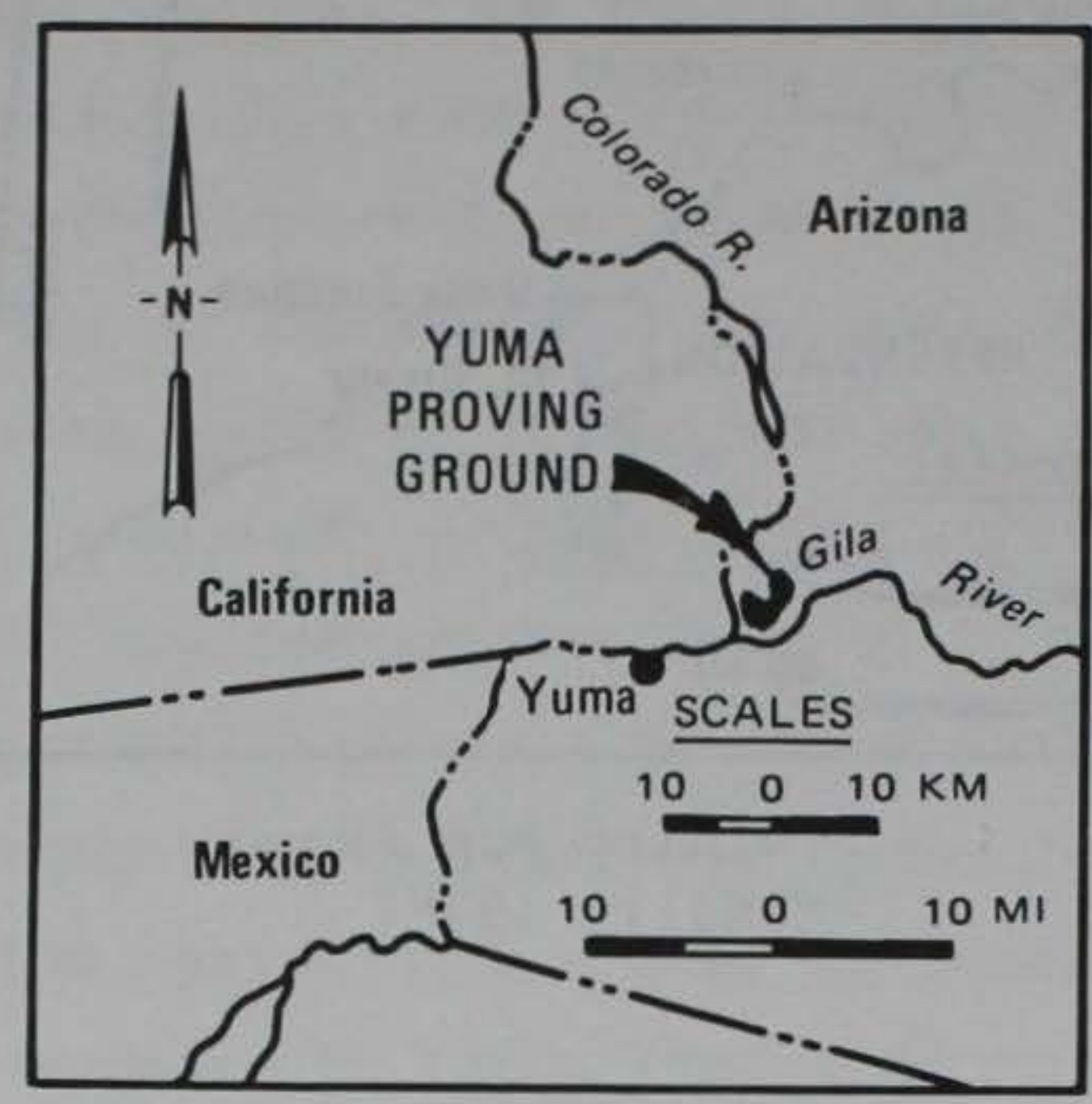

a. Vicinity map (Rand
McNally 1978)

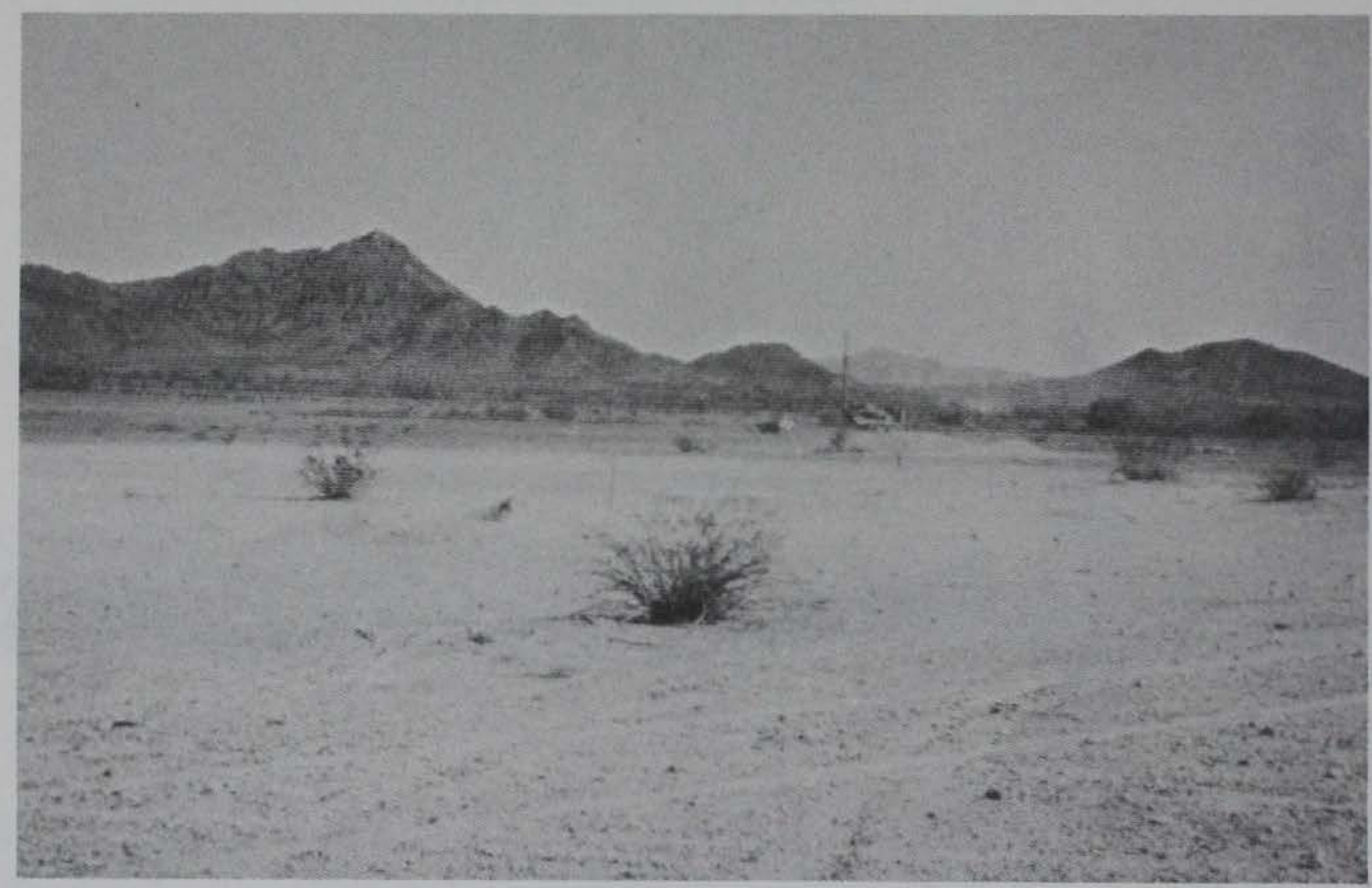

b. Site photograph

Figure 11. Test site at Yuma Proving Ground 


\section{PART III: TEST RESULTS}

\section{Auger Performance}

24. As would be expected, the auger performed best in moist, fine-grained material such as that found at the BBTS and Harry S. Truman Reservoir. In these locations, the borehole could be completed in about $3 \mathrm{~min}$. This could be increased to $15 \mathrm{~min}$ where moisture content was low - less than 10 percent - and the soil dense. At Yuma Proving Ground, the dry, granular soil would run off the auger and was difficult to remove from the borehole. Pouring water into the borehole during boring improved this situation. Some soft, friable rock resembling caliche was encountered, but penetration was achieved, with boreholes being completed in 20 to $30 \mathrm{~min}$. The poorest performance was recorded in gravelly to rocky soils, such as those found at Fort Greely and Fort Leonard Wood. In the coarse gravel of Fort Greely, more than one attempt was usually necessary to achieve the desired depth, since the auger could not bypass the larger particles. When frozen (tests were conducted in both summer and winter), it was not possible to achieve depths greater than about $8 \mathrm{in.}$ in this material. At Fort Leonard Wood, cobbles up to about 5 in. blocked attempts to complete boreholes.

\section{Explosive Design Performance}

25. The single charges performed as expected, with results (Table 1) falling within the ranges previously established by Strange (1961).

26. Table 2 contains results of the double charges. In reviewing these, several general observations may be made.

a. Overall, the best results were obtained when the top charge was smaller than the bottom charge. The optimum ratio top: bottom appeared to be about $1: 2$.

b. The best camouflet was obtained with a 1-1b lower charge, with $\mathrm{D} \approx 2.6 \mathrm{ft}$.

c. The best results were obtained on Shot $7 \mathrm{~T} 5$, where the upper $0.5-1 \mathrm{~b}$ charge was buried at a scaled depth of $2.13 \mathrm{ft} / 1 \mathrm{~b}^{1 / 3}$. 
PART IV: DISCUSSION, CONCLUSIONS, AND RECOMMENDATIONS

\section{Discussion}

\section{Charge placement}

27. The auger adaption performs well in many "ordinary" soils, but may be unsuitable in soils with a high gravel content, especially when such soils are frozen. Whether it offers any improvement in performance over the shaped charge concept could be resolved by a time-andeffort study involving the construction of foxholes by these methods. It does, however, offer an explosive method of foxhole construction with a relative low signature (noise and flash); this, too, could be quantified in side-by-side experiments. It also has some flexibility not available in the shaped-charge method in that the augered hole depth can be adjusted to suit the charge and soil conditions.

28. If the method developed in this study is adopted, further work is needed.

a. Charge size/placement combinations should be more carefully examined in a variety of soils.

b. The auger design should be examined with an eye toward reducing its weight (perhaps by using a lighter metal alloy) and strengthening its connections. Consideration should be given to an adapter that would allow it to be power driven when a power source might be available.

Explosive design

29. While purposely excluded from this test, the idea of a delay between charges has merit. Presumably, the upper charge should fire a few milliseconds before the lower charge for best results. For placement in the hands of nonengineer troops, a precut detonating cord with built-in delay would probably be best.

\section{Conclusion}

30. The expedient method researched in this study offers promise for rapid foxhole construction with reduced signature, within a limited 
range of conditions. It is deserving of conditional adoption for additional study.

\section{$\underline{\text { Recommendations }}$}

31. It is recommended that the foxhole construction method of this study be published in appropriate literature (e.g., Field Manuals 5-15, 5-34) as an expedient technique, perhaps illustrated as in

Figure 12. It would require fabrication of an auger at unit level.

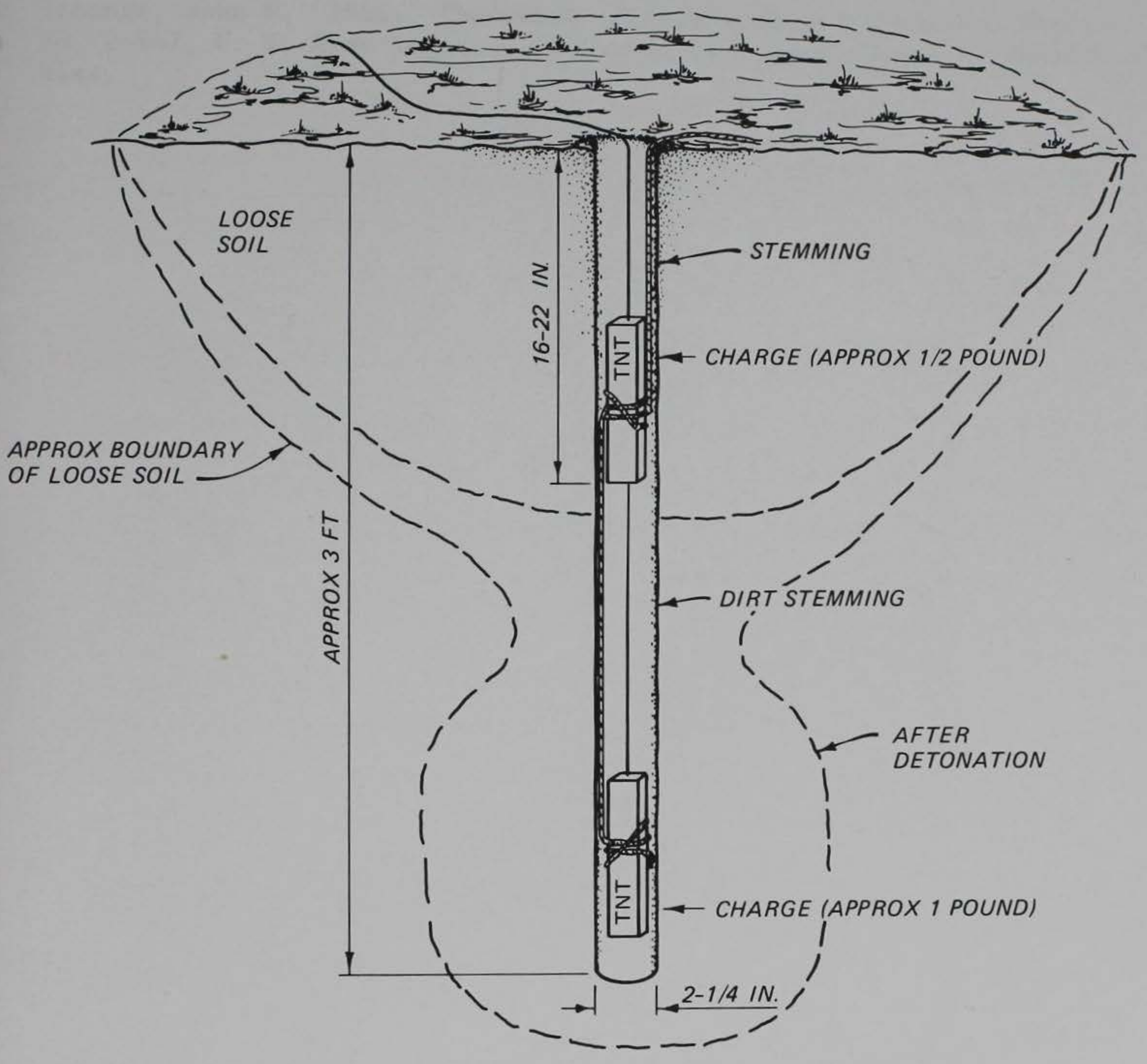

Figure 12. Illustration of two-charge foxhole 
32. It is further recommended that this method be given more careful study under a wider variety of conditions with an eye toward adopting it as a standard technique, with accompanying hardware design by an appropriate Army agency. 


\section{REFERENCES}

Carleton, H. D., Sullivan, J. J., and Rooke, A. D., Jr. "Cratering and Ditching Experiments with Slurry Blasting Agents, FY75-FY78" (in preparation), U. S. Army Engineer Waterways Experiment Station, Vicksburg, Miss.

Headquarters, Department of the Army. 1968. "Field Fortifications," FM 5-15, Washington, D. C.

D. C.

. 1971. "Explosives and Demolitions," FM 5-25, Washington,

Rand McNally. 1978. "Road Atlas, United States, Canada, and Mexico," 54 th Annual Edition, New York, N. Y.

Strange, John N. 1961. "Analysis of Crater Data," Technical Report

No. 2-547, U. S. Army Engineer Waterways Experiment Station, Vicksburg, Miss. 
Table 1

Single-Shot Results

\begin{tabular}{|c|c|c|c|c|c|}
\hline \multirow[b]{2}{*}{$\begin{array}{c}\text { Shot } \\
\text { Designation }\end{array}$} & \multicolumn{2}{|c|}{ Charge } & \multicolumn{2}{|c|}{ Apparent Crater } & \multirow{2}{*}{$\begin{array}{l}\text { True } \\
\text { Crater } \\
\text { Depth } \\
\text { in. } \\
\end{array}$} \\
\hline & $\begin{array}{c}\text { Ch } \\
\text { Weight } \\
\text { lb } \\
\end{array}$ & $\begin{array}{l}\text { DOB } \\
\text { in. }\end{array}$ & $\begin{array}{c}\text { Diameter } \\
\text { in. }\end{array}$ & $\begin{array}{l}\text { Max. } \\
\text { Depth } \\
\text { in. }\end{array}$ & \\
\hline $2 \mathrm{~T} 1$ & 0.75 & 11.0 & 43.5 & 15.5 & 42 \\
\hline $2 \mathrm{~T} 2$ & 0.75 & 12.0 & 43.0 & 10.5 & 49 \\
\hline $3 \mathrm{~T} 1$ & 0.75 & 16.2 & 43.0 & 12.0 & 49 \\
\hline $3 \mathrm{~T} 2$ & 0.75 & 16.2 & 45.0 & 12.0 & 51 \\
\hline $3 \mathrm{~T} 3$ & 0.75 & 16.2 & 40.0 & 11.5 & 47 \\
\hline $4 \mathrm{Tl}$ & 0.75 & 21.2 & 40.0 & 9.0 & $54+*$ \\
\hline $4 \mathrm{~T} 2$ & 0.75 & 21.2 & 59.0 & 9.0 & $54+*$ \\
\hline $5 \mathrm{~T} 1$ & 0.50 & 20.5 & 47.0 & 17.0 & NM*** \\
\hline $5 \mathrm{~T} 2$ & 0.50 & 32.5 & 43.0 & 20.5 & NM** \\
\hline $5 \mathrm{~T} 3$ & 0.50 & 14.5 & 47.0 & 18.0 & NM** \\
\hline
\end{tabular}

* Exceeded depth of probe.

** NM not measured. 
Table 2

Double-Shot Results*

\begin{tabular}{|c|c|c|c|c|c|c|c|c|}
\hline $\begin{array}{c}\text { Shot } \\
\text { Designation } \\
\end{array}$ & $\begin{array}{c}\text { Upper } \\
\text { Weight } \\
1 \mathrm{~b} \\
\end{array}$ & $\begin{array}{r}\text { Charge } \\
\text { DOB } \\
\text { in. }\end{array}$ & $\begin{array}{c}\frac{\text { Lower }}{\text { Weight }} \\
\text { 1b } \\
\end{array}$ & $\begin{array}{l}\frac{\operatorname{arge}}{\mathrm{DOB}} \\
\text { in. }\end{array}$ & $\begin{array}{c}\text { Apparent } \\
\text { Diameter } \\
\text { in. } \\
\end{array}$ & $\begin{array}{l}\text { Crater } \\
\text { Maximum } \\
\text { Depth } \\
\text { in. } \\
\end{array}$ & $\begin{array}{l}\text { Depth to } \\
\text { Top of } \\
\text { Camouflet } \\
\text { in. } \\
\end{array}$ & Remarks \\
\hline $6 \mathrm{~T} 1$ & 0.50 & 18.0 & 0.50 & 34.2 & 39.0 & & & \\
\hline $6 \mathrm{~T} 2$ & 0.75 & 18.0 & 0.50 & 34.2 & & 37.0 & 30.0 & Upper charge misfired \\
\hline $6 \mathrm{~T} 3$ & 0.50 & 18.0 & 0.75 & 34.2 & & 26.0 & 16.0 & Upper charge misfired \\
\hline $6 \mathrm{~T} 4$ & 0.75 & 17.5 & 0.75 & 34.2 & 48.0 & 27.0 & & \\
\hline $7 \mathrm{~T} 1$ & 0.50 & 21.5 & 0.50 & 34.2 & 36.0 & 14.0 & & \\
\hline $7 \mathrm{~T} 2$ & 0.75 & 22.0 & 0.50 & 34.2 & & 26.0 & 16.0 & Upper charge misfired \\
\hline $7 \mathrm{~T} 3 \mathrm{~A}$ & 0.50 & 22.0 & 0.75 & 34.2 & & 38.5 & 17.0 & Upper charge misfired \\
\hline $7 \mathrm{~T} 3 \mathrm{~B}$ & 0.75 & 22.0 & 0.50 & 34.2 & 45.0 & 10.0 & & \\
\hline $7 \mathrm{~T} 3 \mathrm{C}$ & 0.50 & 22.0 & 0.75 & 34.2 & 47.0 & 21.0 & & \\
\hline $7 \mathrm{~T} 4$ & 0.75 & 22.0 & 0.75 & 34.2 & 43.0 & 17.0 & & \\
\hline $7 \mathrm{~T} 5$ & 0.50 & 20.2 & 1.00 & 34.2 & 48.0 & 34.0 & & \\
\hline $7 \mathrm{~T} 6$ & 0.75 & 22.0 & 1.00 & 34.2 & 45.0 & 12.0 & & \\
\hline $8 \mathrm{~T} 1$ & 0.50 & 15.2 & 1.00 & 34.2 & 46.0 & 17.0 & & \\
\hline $8 \mathrm{~T} 2$ & 0.75 & 15.2 & 1.00 & 34.2 & 45.0 & 21.0 & & \\
\hline $8 \mathrm{~T} 3$ & 0.75 & 17.2 & 1.00 & 34.2 & 46.0 & 21.0 & & \\
\hline $8 \mathrm{~T} 4$ & 0.75 & 20.2 & 1.00 & 34.2 & 36.0 & 15.0 & & \\
\hline $8 \mathrm{~T} 5$ & 0.75 & 22.2 & 1.00 & 34.2 & 41.0 & 14.0 & & \\
\hline $8 \mathrm{~T} 6$ & 0.75 & 16.2 & 1.00 & 34.2 & 42.0 & 11.0 & & \\
\hline $8 \mathrm{~T} 7$ & 0.75 & 12.2 & 1.00 & 34.2 & 37.0 & 18.0 & & \\
\hline 9T1 & 1.00 & 16.2 & 1.00 & 24.0 & 52.0 & 24.0 & & \\
\hline $9 \mathrm{~T} 2$ & 1.00 & 16.2 & 1.00 & 30.0 & 54.0 & 26.0 & & \\
\hline $10 \mathrm{~T} 1 * *$ & 0.50 & 12.0 & 1.00 & 34.0 & 46.0 & 36.0 & & \\
\hline $11 \mathrm{~T} 1 \uparrow$ & 0.62 & 15.9 & 1.25 & 31.8 & 70.0 & 26.4 & & \\
\hline
\end{tabular}

* A11 TNT charges fired at WES BBTS in September 1977, except as noted.

** Fired October 1977 with military dynamite in gravelly clay medium, Fort Belvoir, Virginia.

+ Fired December 1978 with C4 at BBTS. 
1. Field Manual (FM) 5-15, "Field Fortifications," (Department of the Army 1968) provides standards for foxhole construction. The objectives of explosive excavation design are (a) to obtain immediate protection from small arms fire (cover), and (b) to obtain a crater suitable for completion by hand tools, as by removal of loose soil and shaping of final dimensions.

2. Figure $\mathrm{Al}$ is adopted from Figures $2-6,2-8$, and $2-20$ of $\mathrm{FM}$ 5-15, showing an individual foxhole and a design for a crew-served weapon (machinegun). Several dug-in positions for crew-served weapons are contained in FM 5-15; additional research would be necessary to determine what applications the expedient design in this report might have for these various positions.

3. It is recognized that FM $5-15$ is currently under consideration for revision, and that doctrinal changes have taken place in the area of individual protection. It is not felt, however, that these contemplated changes significantly affect this study. 


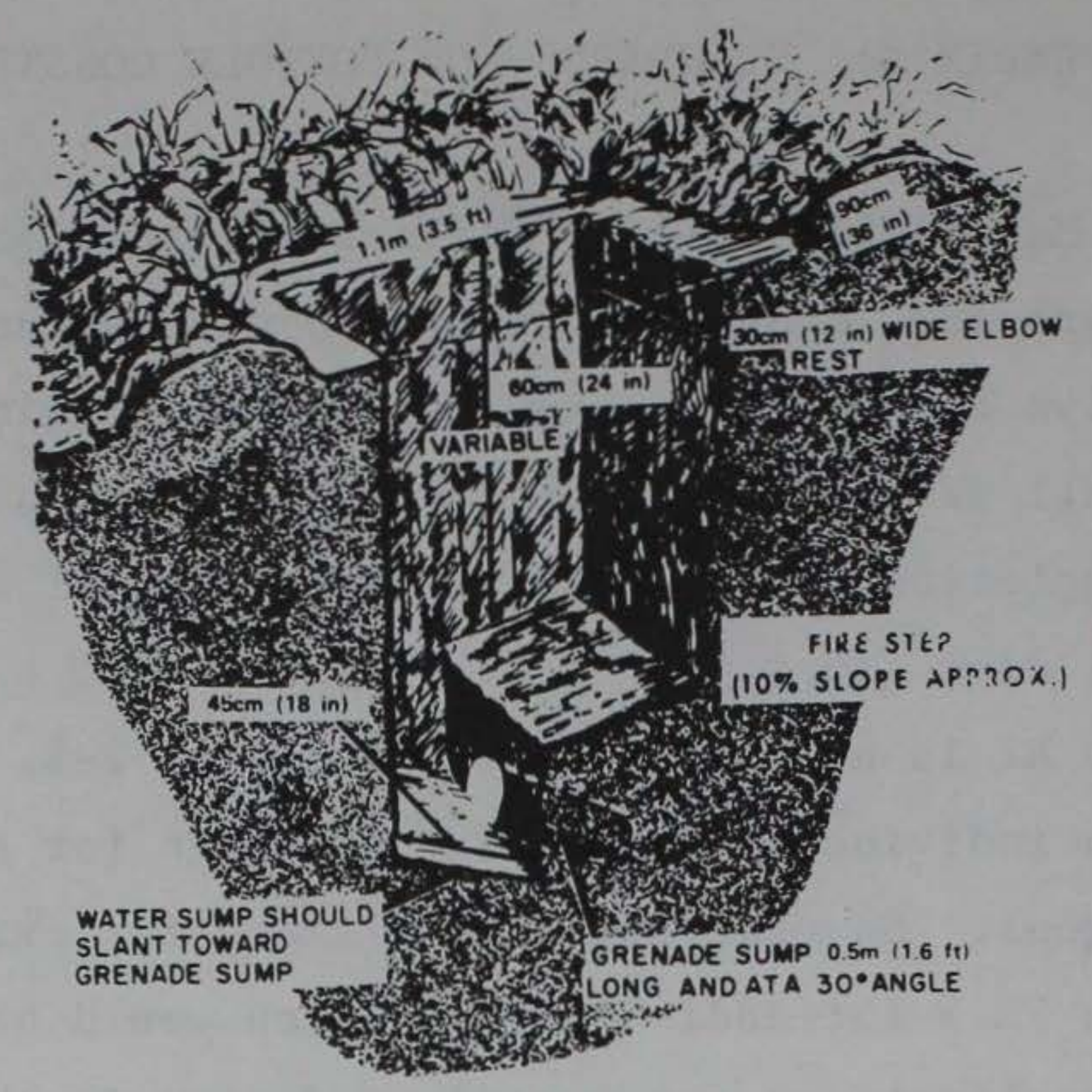

a. Individual foxhole

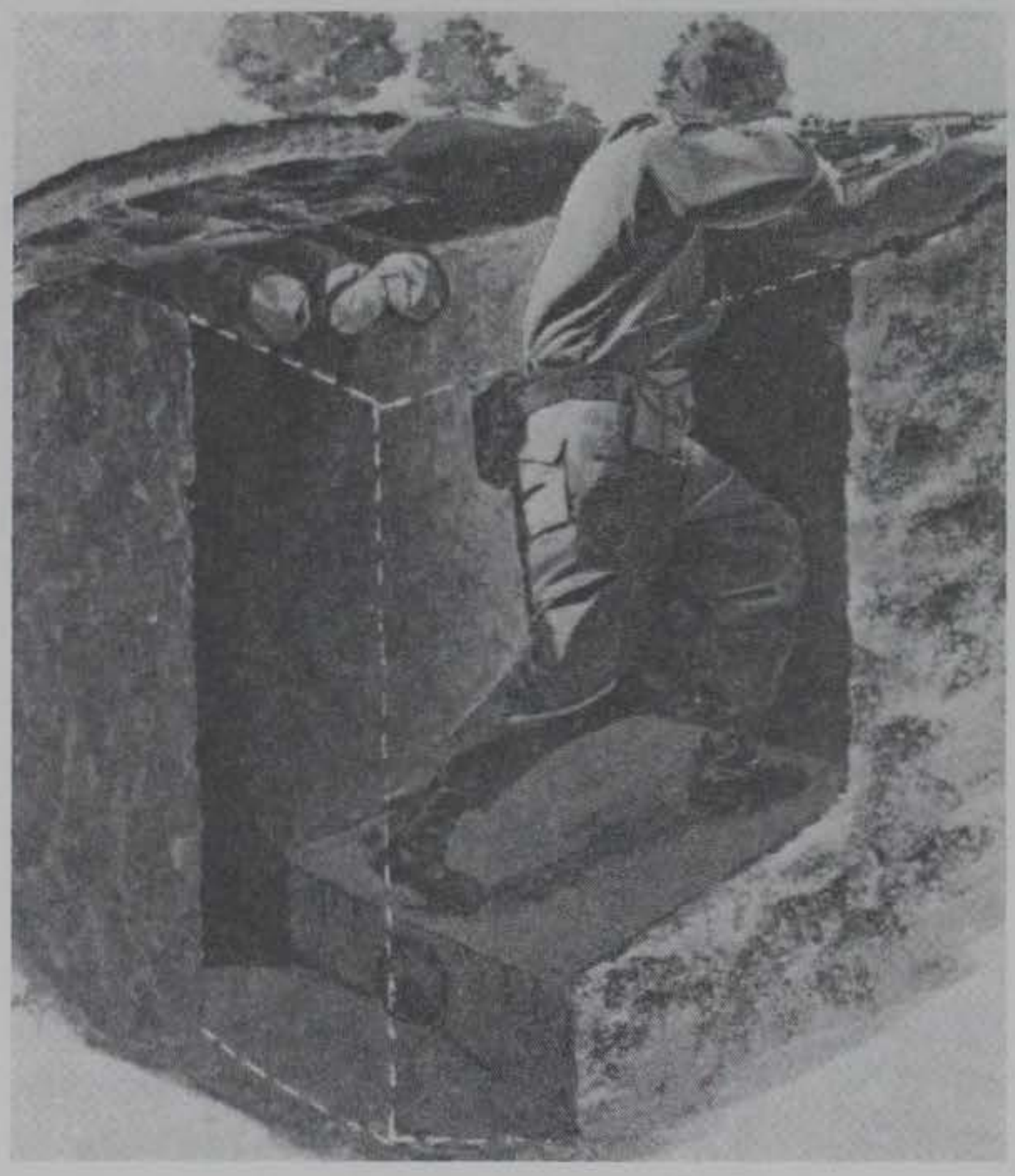

b. Use of individual foxhole (note partial overhead cover)
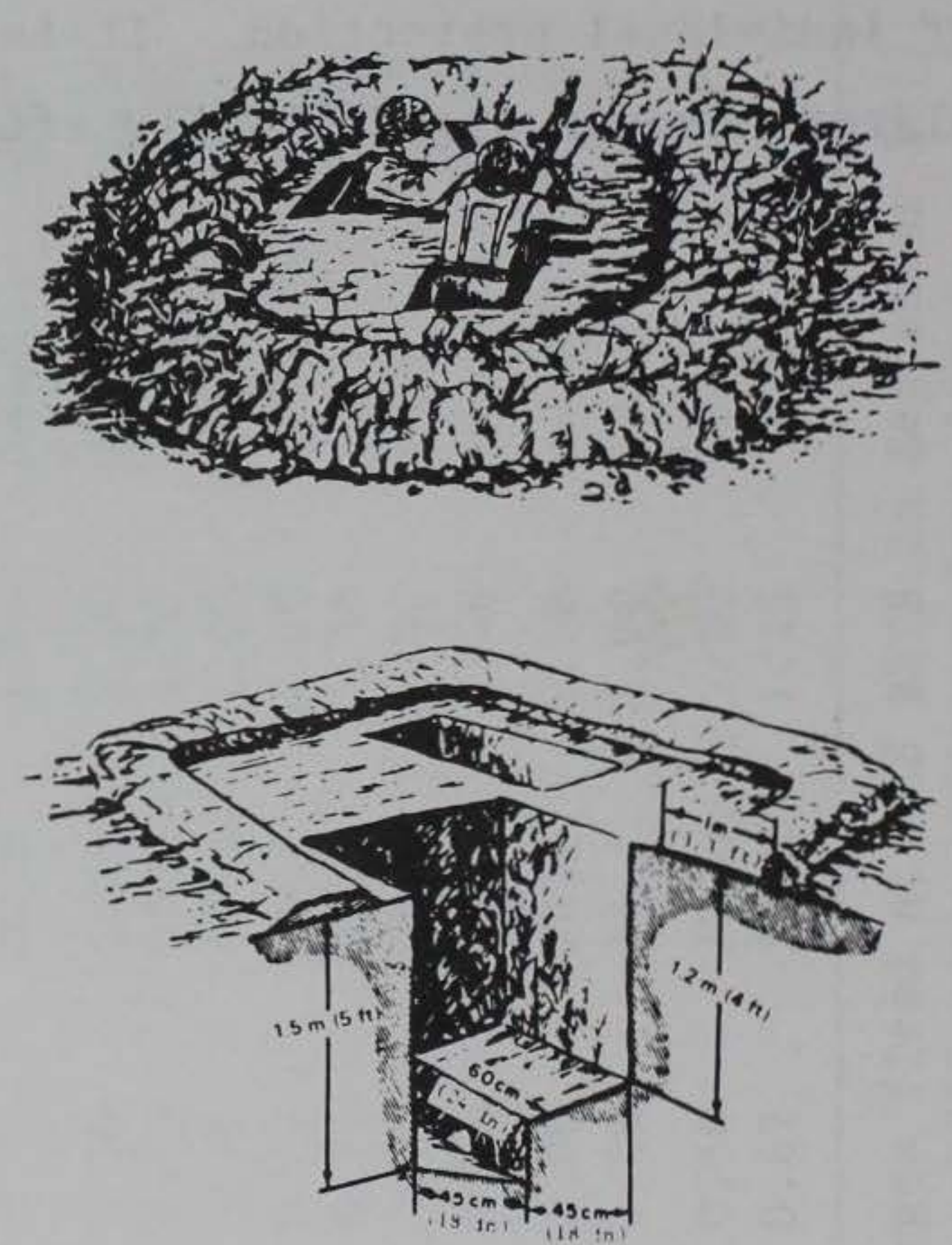

c. Foxholes configured for crewserved weapon

Figure A1. Standards for foxholes 
APPENDIX B: 1977 CONFERENCE ON EXPLOSIVE FOXHOLE EXCAVATION

The following pages reproduce the letter announcement of a 1977 conference on explosive foxhole excavation and the minutes of that conference. These documents serve to give the reader a better understanding of previous as well as current thinking. Abbreviations not otherwise explained in these pages are LOA - letter of authorization and QMR - qualitative materiel requirement. 
SUBJECT: Explosive Foxhole Digger

Commander, 82nd Airborne Division, ATTN: AFVCGC-0, Ft Bragg, NC 28307 Commandant, US Army Infantry School, ATTN: ATCD-CD-MS, Ft Benning, GA 31905 Commandant, US Army Engineer School, ATTN: ATSE-CDM, Ft Belvoir, VA 22060 Commander, US Army Engineer Waterways Experiment Station, ATTN: WESNS, PO Box 631, Vicksburg, MS 39180

1. Reference: Required Operational Capability (ROC) for the Explosive Foxhole Digger (EXFOD), TRADOC ACN 43901 (Proposed Draft).

2. The 82nd Airborne Division drafted a Letter Requirement (LR) for a foxhole digger. The referenced PROC was drafted by the Engineer School in response to the draft LR. The PROC was informally provided to MERADCOM for preliminary comments (Inclosure 1 ). In reviewing the PROC and the requirement for the existing Explosive Kit, Foxhole Digger (NSN 1375-00999-2694) (see Inclosure 2), some questions become apparent regarding the need for a new item development.

3. In order to resolve these questions and to insure that a new ROC accurately defines needs, it is requested that each addressee provide a representative to attend a meeting at MERADCOM on 5 October 1977. At this meeting a film and a possible live demonstration of the existing digger will be seen.

4. MERADCOM point of contact for this meeting will be Mr. H. Smith, AUTOVON 354-5876, Commercial (703) 664-5876.

2 Inc1

as

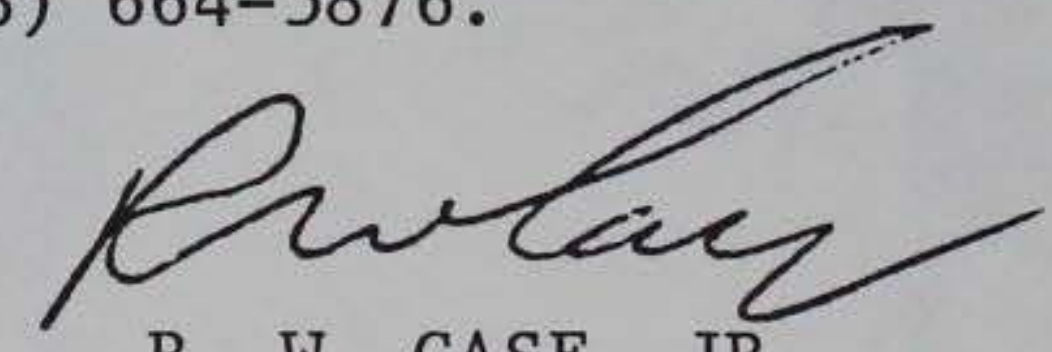

R. W. CASE, JR. LTC, Corps of Engineers Acting Commander 
SUBJECT: Minutes - Foxhole Digging Aid Conference

Commander, US Army Armament R\&D Command, ATTN: DRDAR-LCU-T, Dover, NJ 07801 Commander, 82nd Airborne Division, ATTN: AFVCOC-0, Ft Bragg, NC 28307 Commander, US Army Infantry Schoo1, ATTN: ATCD-CD-MS, Ft Benning, GA 31905 Commander, US Army Engineer School, ATTN: ATSE-CDM, Ft Belvoir, VA 22060 Commander, US Army Engineer Waterways Experiment Station, ATTN: WESNS, PO Box 631, Vicksburg, MS 39180

1. Reference letter to your command dated 25 August 1977 requisting representation at a conference to discuss a proposed new requirement for an explosive foxhole digger.

2. Unfortunately, the 82 nd Airborne was not represented at the conference. Minutes containing two proposed courses of action are transmitted for your information (Inclosure 1).

3. Point of contact is Harry C. Smith, AV 354-5876.

FOR THE COMMANDER:

1 Incl

as

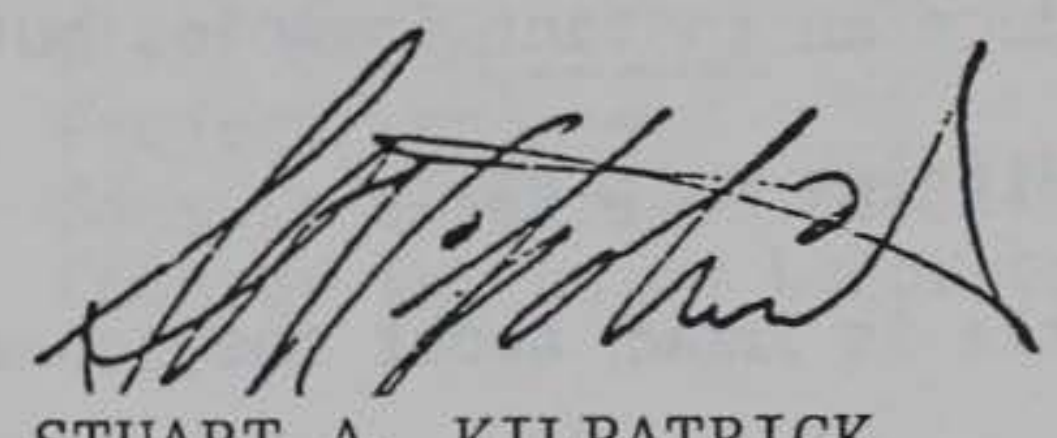

STUART A. KILPATRICK

Acting Chief

Counter Intrusion Laboratory 
Location: NERADCDM, Ft Belvoir, VA.

Date: 5 Oct 1977.

Present: List of attendces (Incl 1).

Purpose: To discuss a proposed new requirement for a foxholc digging aid.

Sumary: An agenda of the conference is attached as Inclosurc 2. Inclosure 3 contains information presented by $\mathrm{Mr}$. Smith in describing anticipated performance of the three devices discussed and their physical characteristics. A projection was also made, estimating the size device required to meet the proposed requirement as originated by the 82 nd Airborne Division.

Technical, operational and logistical problems, implications and proposed solutions were discussed in detail. CPT Woodbury talked briefly about a proposal to combine an auger with the entrenching tool and use of available explosives for the cratering charge. It can generally be stated that the following points were agreed upon:

1. The standard item (officially the Fxplosive Kit, Foxhole Digger but diso referred to as the EL-4) is not satisfactory for use in perma frost, does not produce an instant foxhole, but is useful in loosening the soil to make manual digging much easier.

2. Little is known about the general acceptance of the EL-4 because troops have never had the opportunity to work with it.

3. The 82 nd Airborne's stated requirement is for an application under unique conditions and is not appropriate or representative of the average infantryman's need.

4. The introduction of new, larger, or heavier items of equipment for individual use was viewed with great concern. because of the currently overburdened logistical system. 
The demonstration was an attempt to show the effects of various weight cratering clarges placed at optimun depths, as determined by past experimental programs. The soil conditions were not representative of a broad avcrage, hence, results were quite misleading and not worthy of consideration. Operational firing of the last remaining EL-4 produced expected results; no immediate hole but an area of well pulverized soil approximately four feet in diameter and three feet deep. The soil was very dry, gravely and hard.

Proposed Action: The following course of action was agreed upon, initially falling basically in Mr. Abbott's area of responsibility:

1. Request procurement of a minimum of 2500 standard digging aids to permit evaluation and use by a variety of troop units as a means of determining acceptance by the Army. Administrative procedures required are undetermined at this time.

2. Process the $82 \mathrm{~d}$ Airborne Division request as a special requirement, not as one designed to satisfy all infantry troops.

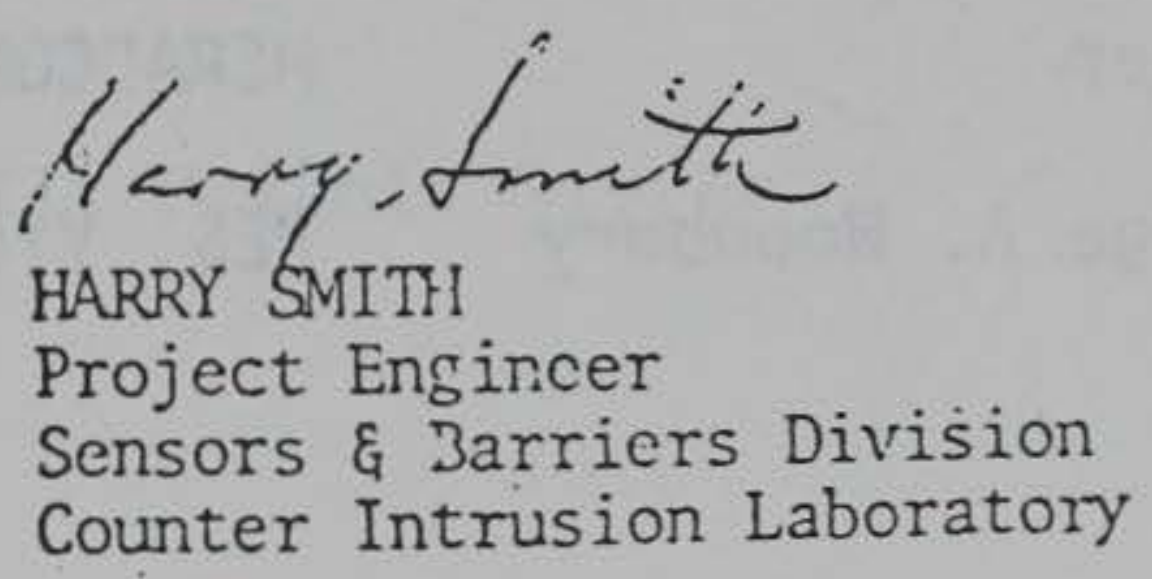


FOX HOLE DIGSER MEETIHG

5 October 1977

Attendees:

Jack Abbott

U.S. Army Eng School

AV $354-1580$

Harry Snith

MERADCOM

AV $354-5876$

Frank Tremain

MERADCOI1

AV $354-5876$

R. Stone

ARRCOM - QAE-P

AV $880-5386$

M. G. Stone

ARRADCOM

AV $880-2575$

Jerold R. Dodds

USAIS

AV 835-5314

CPT James R. Cantrell

USAES

AV $354-3777$

S. A. Kilpatrick

MERADCOM

AV 354-5877

Harry D. Painton

USAES

AV $354-5976$

Harry J. Peters

MERADCOM

AV $354-5877$

Ben Barker

MEPADCOM

AV $354-5741$

CPT George A. Woodbury

WES, Vicksburg, Miss.

Indl 


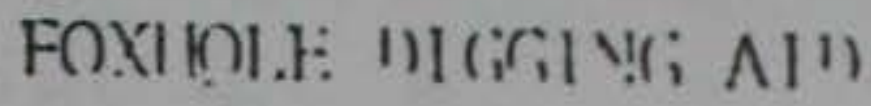

5 nctoher 1977

(R]dg 399 , Conference lionili)

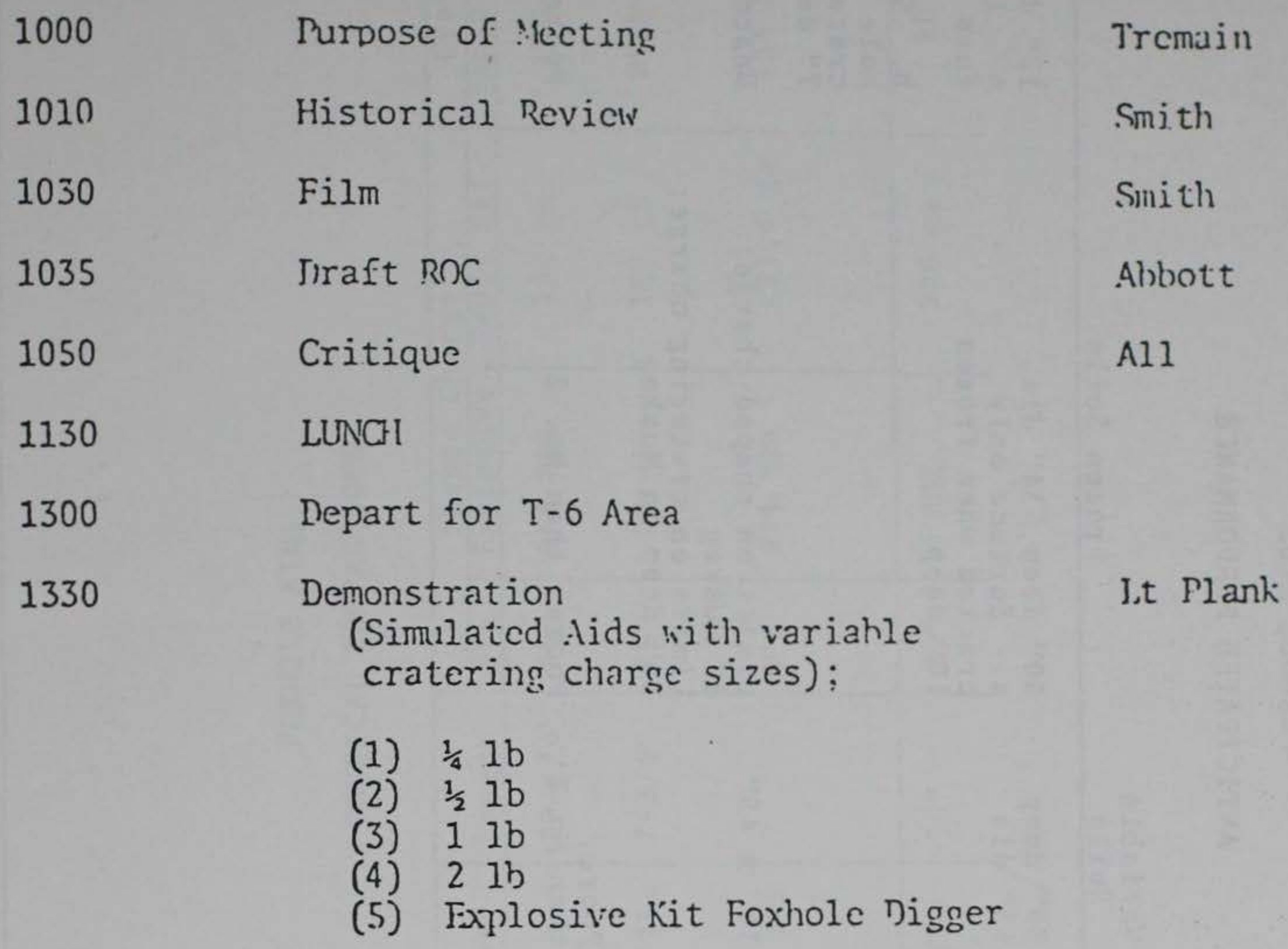

Incl 2 
FOXHOLE AIDS

ANTICIPATED PERFORMANCE

\begin{tabular}{|c|c|c|c|c|}
\hline & Device & $\begin{array}{c}\text { Variable } \\
\text { Soils } \\
\end{array}$ & Frozen Soils & Permafrost \\
\hline & $\begin{array}{l}\text { Explosive Foxhole Digger } \\
\text { ( } 51 \mathrm{~b} \text { - one shot) }\end{array}$ & $\begin{array}{l}36 " \text { deep } \\
53^{\prime \prime} \text { dia }\end{array}$ & $\begin{array}{l}50 " \text { deep, } 34^{\prime \prime} \text { dia. } \\
\text { a. Surface only } \\
\text { cracked when frozen } \\
10^{\prime \prime} \text { deep. }\end{array}$ & $\begin{array}{l}12^{\prime \prime} \text { deep, } 13^{\prime \prime} \text { dia } \\
\text { a. Insufficient for } \\
\text { fuze functioning } \\
\text { b. Shaped charge } \\
\text { hole adequate for } \\
\text { cratering charge - } \\
7 " \text { deep. }\end{array}$ \\
\hline & $\begin{array}{l}\text { Explosive Kit, Foxhole } \\
\text { Digger } \\
\text { (1 lb - two shot) }\end{array}$ & $34^{\prime \prime} \times 45^{\prime \prime}$ & $\begin{array}{l}\text { Limits on shaped charge; } \\
8^{\prime \prime} \text { Muskeg } \\
\text { Limits on cratering charge; } \\
16^{\prime \prime} \text { deep in Muskeg }\end{array}$ & Unacceptable \\
\hline
\end{tabular}

3. Kit Explosive, Digging

Aid L12A1

Poorer

(UK Device; 3 unit,

than No. 2 Poorer than No. 2

Poorer than No. -2

Inc/ 3 
FOXHOLE AIDS

PHYSICAL COMPARISONS

\begin{tabular}{|c|c|c|c|c|c|c|c|c|c|}
\hline \multirow{2}{*}{\multicolumn{3}{|c|}{ Device }} & \multirow[b]{2}{*}{ Weight } & \multirow[b]{2}{*}{ Length } & \multicolumn{3}{|c|}{ Shaped Charge } & \multicolumn{2}{|c|}{ Cratering Charge } \\
\hline & & & & & Dia. & Explosive & Expl. Wgt. & Explosive & Exp1. IIgt: \\
\hline 1. & $\begin{array}{l}\text { Explosive Foxhol } \\
\text { (One shot) }\end{array}$ & e Digger & $5.01 \mathrm{bs}$ & $27-1 / 4^{\prime \prime}$ & $2 \frac{1}{2} "$ & $95 \% \mathrm{RDX}$ & $100 \mathrm{gm}$ & $M B X-6$ & $254 \mathrm{gm}$ \\
\hline 2 . & $\begin{array}{l}\text { Explosive Kit, F } \\
\text { Digger } \\
\text { (Standard) }\end{array}$ & oxhole & $1.01 \mathrm{bs}$ & $7-3 / 8 "$ & $2 \frac{1}{2} "$ & Octol & $117 \mathrm{gm}$ & DBXN-1 & $162 \mathrm{gm}$ \\
\hline 3 & $\begin{array}{l}\text { Kit Explosive, D } \\
\text { Aid Li2A1 } \\
\text { (3 devices) }\end{array}$ & igging & $5.31 \mathrm{bs}$ & & $2 \frac{1}{\xi} "$ & 928 RDX & $93.4 \mathrm{gm}$ & $73 \%$ RDX & $113.3 \mathrm{gm}$ \\
\hline & $\begin{array}{l}\text { As Indicated by } \\
\text { ments }\end{array}$ & Require- & $101 \mathrm{bs}$ & $30^{\prime \prime}$ & $3 \frac{1}{2} "$ & RDX & $908 \mathrm{gm}$ & RDX & $908 \mathrm{gm}$ \\
\hline
\end{tabular}




\section{Comparisons}

(Requirements)

\begin{tabular}{|c|c|c|c|c|}
\hline & Characteristic & $\begin{array}{c}\text { Original Requirement } \\
(1959)\end{array}$ & $\begin{array}{l}\text { Existing Item } \\
\text { Requirement } \\
(1962)^{*}\end{array}$ & $\begin{array}{l}\text { PROC } \\
(1977)\end{array}$ \\
\hline & Device Weight & $5 \mathrm{lb}$ & $1 \mathrm{lb}$ & $5 \mathrm{lb}$ \\
\hline \multirow{3}{*}{ ケ } & Foxhole Size & $\begin{array}{l}\text { About } 48 \text { " deep } \\
\text { Maximum Dtameter } 42^{\prime \prime}\end{array}$ & $\begin{array}{l}\text { Minimum depth } 17^{\prime \prime} \\
\text { Minimum diameter } 20^{\prime \prime} \\
\text { Acceptable performance } \\
\text { in } 8 \text { "frozen sol } 1\end{array}$ & $\begin{array}{l}\text { Minimum depth } 36 " \\
\text { Minimum diameter } 48 "\end{array}$ \\
\hline & Timing & $\begin{array}{l}\text { Produce required } \\
\text { hole in } 2 \mathrm{~min} .\end{array}$ & $\begin{array}{l}\text { Unpack, assemble, and } \\
\text { fire - less than } 1 \mathrm{~min} \text {. }\end{array}$ & $\begin{array}{l}\text { Produce required } \\
\text { hole in } 2 \mathrm{~min} \text {. }\end{array}$ \\
\hline & Bullet Impact & $\begin{array}{l}\text { Wi11 not explode or } \\
\text { flash burn }\end{array}$ & $\begin{array}{l}\text { Wi11 not detonate main. } \\
\text { charges }\end{array}$ & $\begin{array}{l}\text { Will not initiate } \\
\text { explosive. }\end{array}$ \\
\hline
\end{tabular}

1959 Major Deficiences - Too long, too heavy, non-performance within 2 minutes. Minor Deficiences - Diameter of hole too large, failure on bullet impact.

*Type Classified in 1966. 
The foll'owing paragraphs provide representative information on the two diggers developed and tested at MERADCOM.

\section{FOXHOLE AID}

A. Explosive Foxhole Digger 1

1. Packaged weight

$$
5.0 \mathrm{lbs}
$$

Packaged length

$27 \frac{1}{4}$ in.

Height in firing position

31 in.

Shaped Charge (95\% RDX)

$100 \mathrm{gm}:$

Cratering Charge (MBX-6)

$254 \mathrm{gm}$.

2. Performance - Ft Churchill

Permafrost

Insufficient penetration for fuze functioning

*(12 deep \& 13 in. dia.)

3. Ice

*Depth

$18^{\prime \prime}$

20"

$19 "$
*Diameter

$48^{\prime \prime}$

$48^{\prime \prime}$

$48^{\prime \prime}$

4. Frozen Soil

10 in. frozen soil - surface only cracked crater $50^{\prime \prime *}$ deep $x$ $34^{\prime \prime *}$ diameter.

5. Variable Soil

*Depth $\quad$ *Diameter

$36^{\prime \prime}$

$53^{\prime \prime}$

(typical)

$40^{\prime \prime}$

$50 "$

$40^{\prime \prime}$

$60^{\prime \prime}$

1 Report 1552-TR, 28 October 1958

*Note: The dimensions listed are representative only. 
6. Shaped Charge test on permafrost produced holes less than 1-1/4 in. dia. at depths of $5 \mathrm{in}$. and $3 / 4 \mathrm{in}$. dia. to depths of $7 \mathrm{in}$.

7. Cratering charge - When placed at optimum depth in hard soils, the hole was only $3 \frac{1}{2} \mathrm{ft}$ deep (vs $4 \mathrm{ft}$ desired). The $2 \mathrm{ft}$ dia. at the bottom and the shallow depth indicated a larger cratering charge was required.

B. Explosive Kit, Foxhole Digger 2

Model EL-4 (ET/ST) - Type Classified Standard-A for temperate zone use on 31 March 1966.

1. Packaged weight 1.07 lbs.

Length

7.38 in.

Shaped Charge (Octol-75\% HMX, 25\% TNT) $117 \mathrm{gm}$.

Cratering Charge (PBXN-1)

$162 \mathrm{gm}$.

2. Performance (typical)

*Depth

*Diameter

Lean clay, frozen $2 \frac{1}{2}-3$ in.

$34^{\prime \prime}$

$45^{\prime \prime}$

Rocky clay

$32^{\prime \prime}$

$47^{\prime \prime}$

3. ET/ST model $3 \%$ dud rate (5\% allowed, $1 \%$ desired)

${ }^{2}$ Report 1934, September 1968

*Note: The dimensions listed are representative only. 


\section{EXPLOSIVE FOXHOLE DIGGER}

(Comments on Proposed Draft ROC)

1. The user must decide whether or not there will be a requirement to satisfactorily operate in permafrost. Permafrost is very difficult and an item that will perform satisfactorily will cause an "over-kill" in almost all other situations.

2. The wide variation in soils makes it very difficult to design a device to perform within the narrow limits specified for a foxhole. A compromise must be worked out between the user and the designer, producing an item that will provide minimum protection under the most difficult conditions. An example is contained in the Technical Characteristics approved as a part of the 1962 OMR for a similar item (EL-4). The specific numbers should be reexamined for today's environment.

3. It should be made clear whether or not the device is to produce an instant foxhole in a specified time, or whether some manual removal of soil is expected. One approach might be to produce the minimum hole instantly, followed by manual spoil removal to produce the desired foxhole.

4. The user should examine his requirement for a one-shot device. Considerable bulk, length and cost and reliability are associated with this requirement vs a two-step device.

5. Immunity to small arms initiation should realistically be limited to insurance that neither the shaped charge, nor the cratering charge will be initiated. Protection against,burning of the rocket propellant (if present), or initiation of the sensitive primers and firing train is not considered realistic. 
6. A requirement for limiting the acoustic signature has not been stated. If the acoustic signature is 1 imited, the requirement should be stated as soon as possible.

7. If the user will be satisfied with a slightly larger (containing more explosive) version of the item Service Tested in 1959, then the requirement document may be a ROC, however, if the requirements as relate to items $1,2,3$ and 5 above are not tempered and considered carefully, as indicated, then the appropriate document would be a LOA, permitting 6.3 work before entering the 6.4 effort. 